\section{Research Square}

Preprints are preliminary reports that have not undergone peer review. They should not be considered conclusive, used to inform clinical practice, or referenced by the media as validated information.

\title{
Biocontrol potential of endophytic fungus Talaromyces trachyspermus against root rot pathogens of sunflower
}

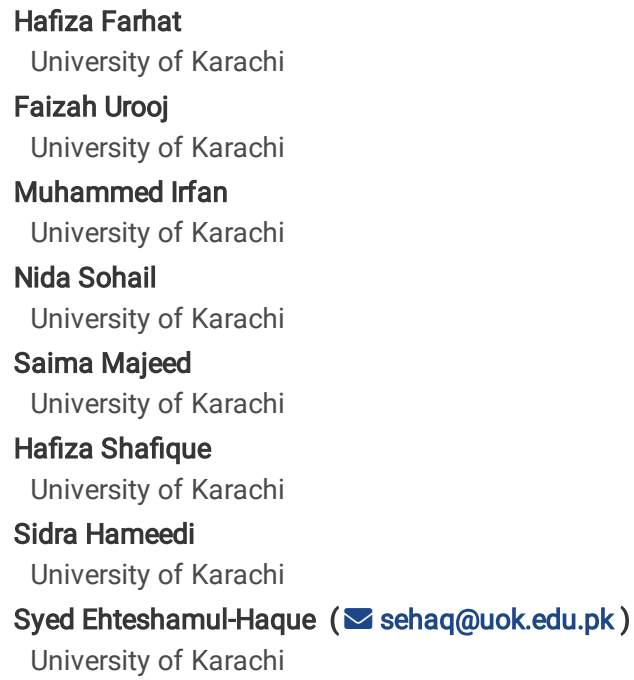

Research Article

Keywords: Endophytic fungi, antimicrobial, biocontrol, sunflower, biochemical markers, compounds, GC-MS.

Posted Date: March 16th, 2021

DOI: https://doi.org/10.21203/rs.3.rs-275521/v1

License: @ (i) This work is licensed under a Creative Commons Attribution 4.0 International License. Read Full License 


\section{Abstract}

Several reports revealed that endophytic fungi have great influence on host plants, as they promote plant growth and minimize disease severity caused by various pathogens. In this study, endophytic fungi isolated from healthy plants were identified as Aspergillus terreus, Curvularia lanata, C. hawaiiensis, Macrophomina phaseolina, Fusarium solani, Talaromyces assiutensis and T. trachyspermus were evaluated for antimicrobial activity, using dual-culture plate assay and agar disc diffusion method. They have shown significant activity against root rot pathogens, Macrophomina phaseolina, Rhizoctonia solani, Fusarium solani and F.oxysporum. Talaromyces assiutensis and T. trachyspermus were selected for further study, since other fungi are well known plant pathogens or environmental contaminants. They were applied in pots and field plot experiments using sunflower as test plant. There efficacy was also compared with endophytic Cephalosporium sp., and Chaetomium sp. Talaromyces spp., significantly suppressed root rotting fungi and improved plant biomass. They ameliorated production of plant defense biochemical markers (polyphenolic content and salicylic acid) and antioxidant potential of treated plants. GC-MS profiling of $n$-hexane fraction of T. trachyspermus yielded several new compounds from this source. Endophytic fungi associated with healthy plants have great potential to suppress root rotting fungi and stimulate production of plant's defense biochemical markers.

\section{Introduction}

Endophytic fungi are the microorganisms that live inside plant tissues but do not cause any disease ${ }^{1,2,3}$. Recent reports show that they have great influence on host plants as they promote plant growth, minimize disease severity, produce antiherbivore/antimicrobial products and improve defense mechanism ${ }^{4,5,6,7}$. Endophytic fungi produce bioactive compounds, involved in increasing the adaptability of fungi and their host, utilization of nutritional elements in the form of nitrogen and phosphorus which are beneficial for plants ${ }^{8,9}$. They improved plant growth via secretion of different hormonal substances and plant's defense biochemical markers ${ }^{10}$. Penicillium species, which are environment contaminants, are now being reported as endophytes that improve systemic resistance of plants against abiotic and biotic stresses ${ }^{6,11,12,13}$. The IAA produces endophytic Penicillium roqueforti enhanced nutrient uptake by plant and tolerance against stresses ${ }^{14}$. Similarly, it has been reported that solubilization of phosphate by Penicillium oxalicum resulted in improved maize growth, while, Gliocladium sp., an endophytic fungus produces volatile antibiotics identified as Annulene ${ }^{15}$.

Endophytic fungi may have several characteristics which enable them to be widely used as biological control agents ${ }^{16}$. It is now known that mutualistic fungal endophytes may contribute to a wide range of plant tolerance to various biotic and abiotic stresses including elevating resistance level to drought stress to extreme temperatures and high salinity ${ }^{17,18}$. An endophytic fungus Daldinia concentrica has been reported to suppress plant parasitic nematodes, Meloidogyne javanica ${ }^{19}$. Whereas endophytic Trichoderma ${ }^{20}$ and endophytic Penicillium ${ }^{3,6}$ significantly suppressed root rotting fungi on tomato, sunflower and okra. One of the most important threats facing world agriculture is root rot disease caused by fungi that reduces yield and quality in economic crops ${ }^{21,22}$. They also attack sunflower plants in most parts of the world including Pakistan ${ }^{23}$. Stem and root rot disease of sunflowers caused by Fusarium spp., and charcoal rot by Macrophomina phaseolina are major limiting factors in sunflower growth ${ }^{22,24}$. Endophytic fungi produce bioactive compounds and have suppressive effects on pathogenic fungi are emerging as possible alternatives to chemical pesticides ${ }^{3,5,6}$. This study describes the isolation, identification, molecular characterization and antimicrobial potential of endophytic Talaromyces species associated with healthy plants. Biocontrol potential of some endophytic fungi against root rotting fungi was also evaluated using sunflower as a test plant. GC-MS profiling of $n$-hexane fraction of culture filtrate of endophytic Talaromyces trachyspermus is also being reported here.

\section{Results}

Morphological Identification of endophytic fungi. The endophytic fungi isolated were identified as Aspergillus terreus, Curvularia lanata, C.hawaiiensis, Macrophomina phaseolina, Fusarium solani, Talaromyces assiutensis and T. trachyspermus on the basis of morphological characters (Table 1). 
Table 1

Growth inhibition of Macrophomina phaseolina, Rhizoctonia solani, Fusarium solani and F. oxysporum in dual culture plate assay by the endophytic fungi isolated from different wild and cultivated plants.

\begin{tabular}{|c|c|c|c|c|c|}
\hline \multirow[t]{2}{*}{ Fungi } & \multirow[t]{2}{*}{ Host name } & M. phaseolina & R. solani & F. solani & F. oxysporum \\
\hline & & \multicolumn{4}{|c|}{ Zone of inhibition (mm) } \\
\hline $\begin{array}{l}\text { Chaetomium sp. } \\
\text { (KUCC-1359) }\end{array}$ & $\begin{array}{l}\text { Momordica charantia L. } \\
\text { (G.H.No. 94618) }\end{array}$ & $29^{c} \pm 4.9$ & $15^{\mathrm{a}} \pm 3.5$ & $25^{b c} \pm 2.1$ & $31^{f} \pm 2.9$ \\
\hline Talaromyces assiutensis & $\begin{array}{l}\text { Euphorbia hirta L. } \\
\text { (G.H.No. 12615) }\end{array}$ & $20^{\mathrm{ab}} \pm 1.6$ & $24^{c} \pm 3.8$ & $27^{b c} \pm 1.4$ & $15^{\mathrm{a}} \pm 1.8$ \\
\hline Talaromyces trachyspermus & $\begin{array}{l}\text { Haloxylon stocksii (Boiss.) } \\
\text { (G.H.No. 93479) }\end{array}$ & $25^{\mathrm{bc}} \pm 2.4$ & $26^{c} \pm 3.1$ & $33^{d} \pm 3.1$ & $20^{\mathrm{cd}} \pm 1.8$ \\
\hline Curvularia lanata & $\begin{array}{l}\text { Allium cepa L. } \\
\text { (G.H.No. 95608) }\end{array}$ & $18^{\mathrm{a}} \pm 3.1$ & $16^{\mathrm{ab}} \pm 1.6$ & $30^{\mathrm{a}} \pm 1.8$ & $25^{a b} \pm 2.1$ \\
\hline Curvularia hawaiiensis & Euphorbia hirta L. & $20^{\mathrm{ab}} \pm 1.6$ & $16^{\mathrm{ab}} \pm 3.1$ & $18^{\mathrm{a}} \pm 1.9$ & $27^{\mathrm{e}} \pm 0.81$ \\
\hline Fusarium solani & $\begin{array}{l}\text { Chenopodium album L. } \\
\text { (G.H.No. 89235) }\end{array}$ & $25^{b c} \pm 2.4$ & $16^{\mathrm{ab}} \pm 3.1$ & $16^{\mathrm{a}} \pm 2.1$ & $20^{\text {cd }} \pm 1.4$ \\
\hline Macrophomina phaseolina & $\begin{array}{l}\text { Indigofera hochstetteri Baker } \\
\text { (G.H. No. 38211) }\end{array}$ & $17^{c} \pm 4.9$ & $19^{b c} \pm 2.1$ & $18^{\mathrm{b}} \pm 3.0$ & $27^{d} \pm 2.2$ \\
\hline Aspergillus terreus & $\begin{array}{l}\text { Sida ovata Forssk. } \\
\text { (G.H. No. 12278) }\end{array}$ & $15^{\mathrm{a}} \pm 3.5$ & $20^{\mathrm{abc}} \pm 4.7$ & $15^{\mathrm{a}} \pm 1.9$ & $18^{b c} \pm 1.8$ \\
\hline Fusarium solani & $\begin{array}{l}\text { Corchorus olitorius L. } \\
\text { (G.H. No. 50663) }\end{array}$ & $18^{\mathrm{a}} \pm 4.3$ & $26^{\mathrm{c}} \pm 1.6$ & $29^{c d} \pm 3.0$ & $25^{\mathrm{e}} \pm 2.4$ \\
\hline Talaromyces assiutensis & $\begin{array}{l}\text { Solanum melongena L. } \\
\text { (G.H. No. 82045) }\end{array}$ & $21^{\mathrm{ab}} \pm 2.0$ & $26^{c} \pm 3.2$ & $17^{\mathrm{cd}} \pm 2.4$ & $28^{\mathrm{cd}} \pm 0.81$ \\
\hline
\end{tabular}

Molecular Identification of endophytic fungi. The dendrogram revealed the genetic relatedness among and between fungal isolates. The fungal genera are divided into three clades. The nucleotide sequence of MK894136, MK894137 and MK894138 are similar to each other. The nucleotide sequence of MK894141, MK894142 and MK894139 are closely related with one another and exhibit sequence similarity at nucleotide level. MK894144 and MK894149 exhibit higher heterogeneity than other species and hence placed into distinct groups within a cluster. Neighbour-Joining phylogenetic tree constructed by MEGA software illustrates that all species were placed into respective groups on the bases of nucleotide similarity (Fig. 1).

Antifungal activity of endophytic fungi in dual culture plate Assay. Endophytic fungi have shown significant activity against four test root rot fungi and produced zones of inhibition. Most of them showed more than $15 \mathrm{~mm}$ zone against M. phaseolina and more than $20 \mathrm{~mm}$ against each $R$. solani, $F$. oxysporum and F. solani (Table 1).

Antifungal activity of culture filtrates of endophytic fungi. Culture filtrates of endophytic fungi were examined against $F$. oxysporum, F.solani, M. phaseolina and $R$. solani, caused inhibition of test fungi and produced inhibition zone of $10 \mathrm{~mm}$ or larger against them at $60 \mu \mathrm{L} / \mathrm{disc}(\mathrm{Table} 2)$. 
Table 2 In vitro growth inhibition of Macrophomina phaseolina, Rhizoctonia solani, Fusarium solani and F. oxysporum by culture filtrates of PGPEF isolated from healthy plants

\begin{tabular}{|c|c|c|c|c|c|}
\hline \multirow[t]{2}{*}{ Fungi } & Culture filtrates & seolina & R. solani & F. solani & F. oxysporum \\
\hline & \multicolumn{4}{|c|}{ Zone of inhibition(mm) } & \\
\hline Control & & $0^{\mathrm{a}} \pm 0.0$ & $0^{\mathrm{a}} \pm 0.0$ & $0^{\mathrm{a}} \pm 0.0$ & $0^{\mathrm{a}} \pm 0.0$ \\
\hline +ve Control & Carbendazim(20 $\mu \mathrm{g} / \mathrm{disc})$ & $5^{\mathrm{bc}} \pm 0.8$ & $7^{\mathrm{bcd}} \pm 1.8$ & $10^{\text {cdef }} \pm 2.0$ & $9^{\text {cdef }} \pm 2.9$ \\
\hline \multicolumn{6}{|c|}{ Chaetomium sp. } \\
\hline & $20 \mu \mathrm{l} / \mathrm{disc}$ & $11^{\text {efghi }} \pm 2.1$ & $10^{\text {defg }} \pm 2.0$ & $9^{\text {cdef }} \pm 2.1$ & $8^{\mathrm{bcd}} \pm 1.8$ \\
\hline & $40 \mu \mathrm{l} / \mathrm{disc}$ & $14^{\mathrm{hijk}} \pm 2.2$ & $15^{\mathrm{klmn}} \pm 2.9$ & $15^{\mathrm{hijk}} \pm 2.4$ & $11^{\text {efg }} \pm 1.9$ \\
\hline & $60 \mu \mathrm{l} / \mathrm{disc}$ & $19^{\operatorname{lmn}} \pm 4.6$ & $19^{\mathrm{lm}} \pm 3.1$ & $21^{\mathrm{mn}} \pm 2.1$ & $19^{\mathrm{ijk}} \pm 2.3$ \\
\hline \multicolumn{6}{|c|}{ Talaromyces assiutensis } \\
\hline & $20 \mu \mathrm{l} / \mathrm{disc}$ & $5^{\mathrm{bc}} \pm 0.8$ & $4^{b} \pm 1.4$ & $5^{\mathrm{bc}} \pm 0.8$ & $7^{b c d} \pm 0.8$ \\
\hline & $40 \mu \mathrm{l} / \mathrm{disc}$ & $10^{\text {cdef }} \pm 2.0$ & $13^{g h i} \pm 3.1$ & $14^{\mathrm{hij}} \pm 2.1$ & $19^{\mathrm{ijk}} \pm 2.2$ \\
\hline & $60 \mu \mathrm{l} / \mathrm{disc}$ & $18^{\mathrm{lmn}} \pm 2.1$ & $18^{\mathrm{mn}} \pm 2.1$ & $19^{\operatorname{lmn}} \pm 2.3$ & $23^{m n} \pm 3.1$ \\
\hline \multicolumn{6}{|c|}{ T. trachyspermus } \\
\hline & $20 \mu \mathrm{l} / \mathrm{disc}$ & $8^{\text {bcdef }} \pm 1.8$ & $9^{\text {cdef }} \pm 2.0$ & $6^{b c} \pm 1.8$ & $10^{\text {cde }} \pm 2.0$ \\
\hline & $40 \mu \mathrm{l} / \mathrm{disc}$ & $15^{\mathrm{jjkl}} \pm 3.6$ & $17^{\mathrm{jkl}} \pm 2.4$ & $15^{\mathrm{hijk}} \pm 1.6$ & $19^{\mathrm{ijk}} \pm 2.5$ \\
\hline & $60 \mu \mathrm{l} / \mathrm{disc}$ & $20^{\mathrm{mn}} \pm 2.5$ & $23^{n} \pm 2.6$ & $21^{\mathrm{mn}} \pm 2.0$ & $24^{\mathrm{n}} \pm 2.9$ \\
\hline
\end{tabular}

Curvularia lanata

\begin{tabular}{lllll}
\hline $20 \mu \mathrm{l} /$ disc & $4^{\mathrm{b}} \pm 1.4$ & $0^{\mathrm{b}} \pm 0$ & $4^{\text {cdef }} \pm 2.3$ & $5^{\mathrm{bcd}} \pm 1.8$ \\
\hline $40 \mu \mathrm{l} / \mathrm{disc}$ & $11^{\mathrm{cdef}} \pm 2.9$ & $8^{\text {cdef }} \pm 2.9$ & $7^{\text {efghi }} \pm 1.8$ & $9^{\text {cde }} \pm 1.9$ \\
$60 \mu \mathrm{l} / \mathrm{disc}$ & $16^{\mathrm{jkl}} \pm 2.4$ & $10^{\mathrm{hij}} \pm 2.2$ & $11^{\mathrm{jkl}} \pm 2.1$ & $12^{\mathrm{ghi}} \pm 2.2$
\end{tabular}

Curvularia hawaiiensis

\begin{tabular}{lllll}
$20 \mu \mathrm{l} / \mathrm{disc}$ & $8^{\mathrm{bcde}} \pm 1.8$ & $4^{\mathrm{d}} \pm 1.0$ & $5^{\mathrm{bc}} \pm 0.8$ & $8^{\mathrm{bcd}} \pm 1.8$ \\
\hline $40 \mu \mathrm{l} / \mathrm{disc}$ & $15^{\mathrm{jkl}} \pm 3.6$ & $7^{\mathrm{bcd}} \pm 1.8$ & $8^{\mathrm{bcde}} \pm 1.8$ & $13^{\mathrm{fgh}} \pm 2.1$ \\
\hline $60 \mu \mathrm{l} / \mathrm{disc}$ & $17^{\mathrm{lmn}} \pm 2.9$ & $12^{\mathrm{fghi}} \pm 1.8$ & $16^{\mathrm{ijkl}} \pm$ & $14^{\mathrm{fgh}} \pm 2.2$
\end{tabular}

Fusarium solani

\begin{tabular}{lcccc}
\hline $20 \mu \mathrm{l} / \mathrm{disc}$ & $6^{\mathrm{bcd}} \pm 1.8$ & $5^{\mathrm{bc}} \pm 0.8$ & $7^{\mathrm{bcd}} \pm 1.4$ & $8^{\mathrm{bcd}} \pm 1.8$ \\
\hline $40 \mu \mathrm{l} / \mathrm{disc}$ & $9^{\mathrm{cdef}} \pm 2.9$ & $8^{\mathrm{bcde}} \pm 1.8$ & $10^{\text {cdef }} \pm 1.8$ & $9^{\text {def }} \pm 2.4$ \\
\hline $60 \mu \mathrm{l} / \mathrm{disc}$ & $13^{\mathrm{ghij}} \pm 3.1$ & $11^{\mathrm{efgh}} \pm 1.9$ & $15^{\mathrm{hijk}} \pm 1.6$ & $16^{\mathrm{hij}} \pm 2.5$
\end{tabular}

Macrophomina phaseolina

\begin{tabular}{lcccc}
\hline $20 \mu \mathrm{l} / \mathrm{disc}$ & $5^{\mathrm{bcde}} \pm 1.8$ & $0^{\mathrm{a}} \pm 0$ & $7^{\mathrm{b}} \pm 2.1$ & $7^{\mathrm{bc}} \pm 0.8$ \\
\hline $40 \mu \mathrm{l} / \mathrm{disc}$ & $9^{\mathrm{fghi}} \pm 1.8$ & $6^{\mathrm{bcde}} \pm 1.6$ & $11^{\mathrm{cde}} \pm 1.4$ & $9^{\mathrm{bcde}} \pm 1.5$ \\
\hline $60 \mu \mathrm{l} / \mathrm{disc}$ & $11^{\mathrm{ikk}} \pm 2.1$ & $12^{\mathrm{ghi}} \pm 1.9$ & $11^{\mathrm{fgh}} \pm 2.1$ & $18^{\mathrm{ghi}} \pm 1.9$
\end{tabular}

Aspergillus terreus

\begin{tabular}{lllll}
\hline $20 \mu \mathrm{l} /$ disc & $5^{\mathrm{bc}} \pm 0.8$ & $4^{\mathrm{b}} \pm 1.4$ & $5^{\mathrm{bc}} \pm 1.9$ & $5^{\mathrm{bc}} \pm 0.8$ \\
\hline $40 \mu \mathrm{l} / \mathrm{disc}$ & $11^{\mathrm{efgh}} \pm 1.9$ & $9^{\mathrm{cde}} \pm 1.9$ & $11^{\mathrm{def}} \pm 0.8$ & $10^{\mathrm{cdef}} \pm 1.7$ \\
\hline $60 \mu \mathrm{l} / \mathrm{disc}$ & $15^{\mathrm{ijk}} \pm 2.2$ & $14^{\mathrm{hij}} \pm 2.1$ & $16^{\mathrm{ijk}} \pm 2.0$ & $14^{\mathrm{fgh}} \pm 2.0$
\end{tabular}

Values in column bearing same superscript letter are not significantly different at $p<0.05$ according to Duncan's multiple range test 
Table 2 In vitro growth inhibition of Macrophomina phaseolina, Rhizoctonia solani, Fusarium solani and F. oxysporum by culture filtrates of PGPEF isolated from healthy plants

Fusarium solani

\begin{tabular}{lllll}
$20 \mu \mathrm{l} / \mathrm{disc}$ & $4^{\mathrm{b}} \pm 1.4$ & $5^{\mathrm{bc}} \pm 0.8$ & $7^{\mathrm{bcd}} \pm 2.1$ & $4^{\mathrm{b}} \pm 1.4$ \\
\hline $40 \mu \mathrm{l} / \mathrm{disc}$ & $10^{\mathrm{d}} \pm 2.0$ & $12^{\mathrm{fgh}} \pm$ & $9^{\text {cdef }} \pm 0.8$ & $8^{\mathrm{bcde}} \pm 1.8$ \\
\hline $60 \mu \mathrm{l} / \mathrm{disc}$ & 1.6 & $17^{\mathrm{efg}} \pm 2.0$ & $15^{\mathrm{hijk}} \pm 1.3$ & $12^{\mathrm{defg}} \pm 1.8$
\end{tabular}

T. assiutensis

\begin{tabular}{lrrrr}
\hline $20 \mu \mathrm{l} /$ disc & $10 \mathrm{~d}^{\mathrm{efg}} \pm 2.0$ & $6^{\mathrm{bc}} \pm 1.8$ & $7^{\mathrm{bcd}} \pm 0.8$ & $7^{\mathrm{bcd}} \pm 0.8$ \\
\hline $40 \mu \mathrm{l} / \mathrm{disc}$ & $17^{\mathrm{klmn}} \pm 2.9$ & $15^{\mathrm{m}} \pm 2.1$ & $17^{\mathrm{jkl}} \pm 1.3$ & $16^{\mathrm{hij}} \pm 1.4$ \\
\hline $60 \mu \mathrm{l} / \mathrm{disc}$ & $21^{\mathrm{n}} \pm 2.1$ & $22^{\mathrm{n}} \pm 2.5$ & $22^{\mathrm{n}} \pm 1.8$ & $20^{\mathrm{jk}} \pm 1.8$
\end{tabular}

Values in column bearing same superscript letter are not significantly different at $p<0.05$ according to Duncan's multiple range test

In vitro antifungal activity of solvent fractions (n-hexane and chloroform) of culture filtrates of endophytic fungi. All endophytic fungi were found to produce $15 \mathrm{~mm}$ or more than $15 \mathrm{~mm}$ zone against $F$. solani and $M$. phaseolina, while more than $10 \mathrm{~mm}$ inhibition zone were measured against $F$. oxysporum and $R$. solani at $60 \mu \mathrm{L} / \mathrm{disc}$ of $n$-hexane soluble fraction. In case of chloroform soluble fraction of endophytes, more than $10 \mathrm{~mm}$ inhibition zone was measured against common phytopathogen including M. phaseolina, R. solani, F. solani, and F. oxysporum at 60 $\mu \mathrm{L} /$ disc (Table 3).

Table 3

In vitro antifungal activity of $n$-hexane and chloroform soluble fractions of culture filtrates of endophytic fungi.

\begin{tabular}{|c|c|c|c|c|c|c|c|c|c|}
\hline \multirow[t]{3}{*}{ Endophytic Fungi } & \multirow{3}{*}{$\begin{array}{l}\text { Conc. of culture } \\
\text { filtrates }\end{array}$} & \multicolumn{8}{|c|}{ Zone of inhibition (mm) } \\
\hline & & \multicolumn{2}{|c|}{ M. phaseolina } & \multicolumn{2}{|l|}{ R. solani } & \multicolumn{2}{|l|}{ F. solani } & \multicolumn{2}{|c|}{ F. oxysporum } \\
\hline & & Hexane & Chloroform & Hexane & Chloroform & Hexane & Chloroform & Hexane & Chloroform \\
\hline & Control & 0 & 0 & 0 & 0 & 0 & 0 & 0 & 0 \\
\hline \multirow[t]{4}{*}{ Chaetomium sp. } & +ve control* & 5 & 10 & 12 & 9 & 10 & 10 & 9 & 15 \\
\hline & $20 \mu \mathrm{l} / \mathrm{disc}$ & 12 & 10 & 8 & 7 & 9 & 6 & 12 & 9 \\
\hline & $40 \mu \mathrm{l} / \mathrm{disc}$ & 17 & 12 & 11 & 9 & 12 & 10 & 16 & 13 \\
\hline & $60 \mu \mathrm{l} / \mathrm{disc}$ & 19 & 15 & 13 & 11 & 17 & 13 & 20 & 16 \\
\hline \multicolumn{10}{|c|}{ Talaromyces assiutensis } \\
\hline & $20 \mu \mathrm{l} / \mathrm{disc}$ & 9 & 7 & 11 & 8 & 9 & 6 & 8 & 5 \\
\hline & $40 \mu \mathrm{l} / \mathrm{disc}$ & 13 & 9 & 14 & 11 & 12 & 9 & 10 & 9 \\
\hline & $60 \mu \mathrm{l} / \mathrm{disc}$ & 17 & 14 & 20 & 14 & 15 & 11 & 16 & 13 \\
\hline \multicolumn{10}{|l|}{$\begin{array}{l}\text { Talaromyces } \\
\text { trachyspermus }\end{array}$} \\
\hline & $20 \mu \mathrm{l} / \mathrm{disc}$ & 8 & 5 & 9 & 7 & 11 & 9 & 6 & 4 \\
\hline & $40 \mu \mathrm{l} / \mathrm{disc}$ & 12 & 9 & 11 & 10 & 13 & 11 & 11 & 8 \\
\hline & $60 \mu \mathrm{l} / \mathrm{disc}$ & 15 & 10 & 15 & 12 & 15 & 13 & 13 & 11 \\
\hline
\end{tabular}

GC-MS profiling of $n$-hexane fraction of culture filtrates of Talaromyces trachyspermus. A total 24 compounds were isolated and identified from $T$. trachyspermus of which 14 compounds were found new from this source when compared at Science finder. New compounds identified are 2-(2-Hydroxy-hex1-enyl)3-methyl-5, 6-di-hydropyrazine, Acetic acid, [3-hydroxy-4-(1-oxopropyl) phenyl] ester, I-Alanine, N-(2-fluorobenzoyl)-, heptadecyl ester, 6-Acetamido-2methylbenzothiazole, 9-[6-Hydroxyhexyl] hypoxanthine, Caffeine, cis-10-Heptadecenoic acid, cis-9-Hexadecenoic acid, Methoxyacetic acid, 2-tetradecyl ester, Cyclopropane-octanoic acid, 1,2-Benzenedicarboxylic acid, diisooctyl ester-, 2-[[2-[(2-ethyl-cyclopropyl)-methyl]- cyclopropyl]-methyl]-, methyl ester-, 3-(1Phenethyl-but-3-enyloxy)-butyric acid, Methoxyacetic acid, 2-pentadecyl ester, Stigmasta-5-22-di-en-3-ol, acetate, (3ß)- (Fig. 2, Supplementary Fig. S-1, S-2, S-3; Supplementary Table S-1).

Effect of endophytic fungi on root rotting fungi and growth of sunflower in pot experiment (2017). No infection of F.solani was observed in Chaetomium sp., and T. trachyspermus treated plants. Chaetomium sp., Cephalosporium sp. and T. assiutensis treated plants showed complete suppression of $F$. oxysporum. T. trachyspermus also completely suppressed M. phaseolina. R. solani was not found in endophytes treated plants as compared to control plants (18.7\%)

Page 5/20 
(Table 4). All endophytic fungi treated plants produced significantly $(p<0.05)$ greater fresh shoot-weight and shoot-length than control plants. Cephalosporium sp., treated plants showed comparatively better results as compared to other endophytic fungi (Table 5).

Table 4

Effects of endophytic fungi on the infection of Fusarium solani, F. oxysporum, Rhizoctonia solani and Macrophomina phaseolina of sunflower roots in pots experiments.

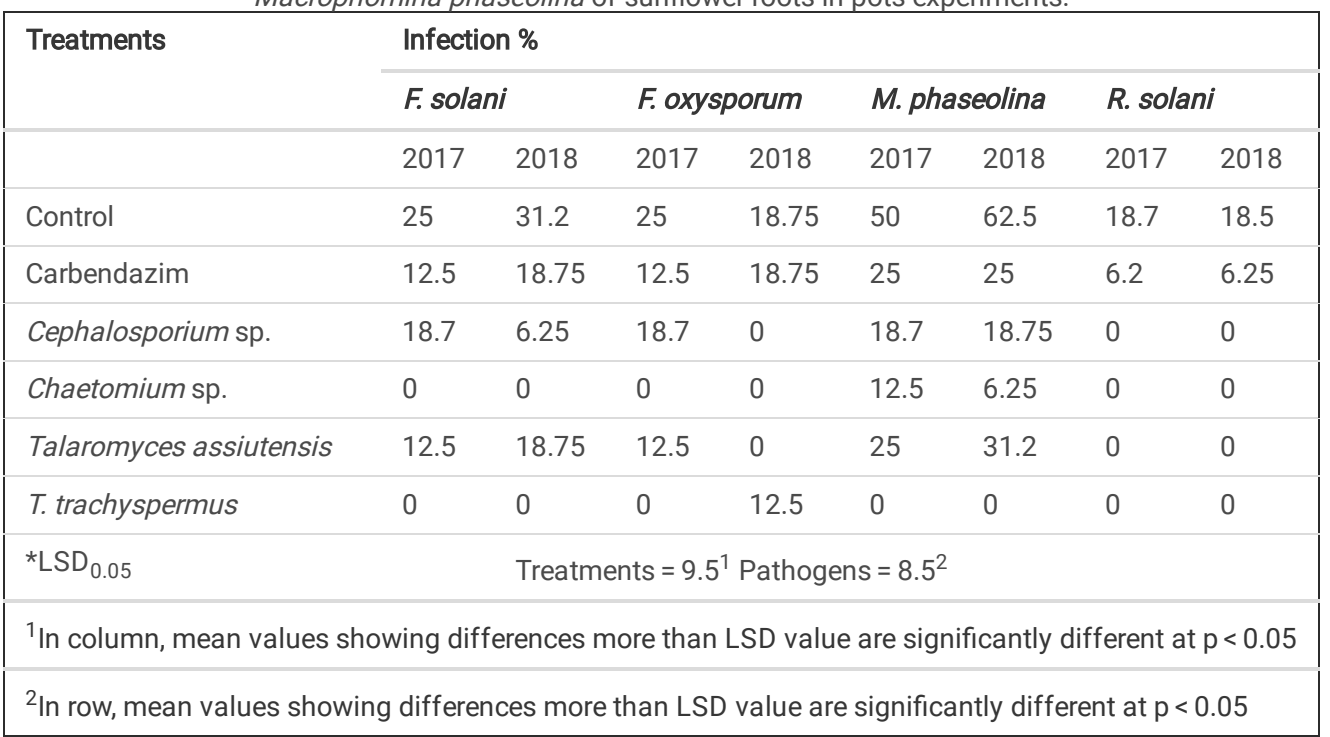

Table 5

Effects of endophytic fungi on growth of sunflower plants in pots experiment.

\begin{tabular}{|c|c|c|c|c|c|c|c|c|}
\hline \multirow[t]{2}{*}{ Treatments } & \multicolumn{2}{|c|}{$\begin{array}{l}\text { Shoot length } \\
\text { (cm) }\end{array}$} & \multicolumn{2}{|c|}{$\begin{array}{l}\text { Shoot wt. } \\
\text { (g) }\end{array}$} & \multicolumn{2}{|c|}{$\begin{array}{l}\text { Root length } \\
\text { (cm) }\end{array}$} & \multicolumn{2}{|c|}{$\begin{array}{l}\text { Root wt. } \\
\text { (g) }\end{array}$} \\
\hline & 2017 & 2018 & 2017 & 2018 & 2017 & 2018 & 2017 & 2018 \\
\hline Control & 29.3 & 30.8 & 5.8 & 5 & 3.9 & 4.2 & 0.4 & 0.3 \\
\hline Carbendazim & 38 & 36 & 9 & 8.3 & 5.4 & 5.4 & 0.6 & 0.5 \\
\hline Cephalosporium sp. & 43.5 & 45.8 & 11.1 & 11.2 & 7.1 & 8 & 1.1 & 1.4 \\
\hline Chaetomium sp. & 38.2 & 39.5 & 9.4 & 8.5 & 7.3 & 6.5 & 0.7 & 1 \\
\hline Talaromyces assiutensis & 34.1 & 35.7 & 7 & 7.2 & 5.6 & 5.1 & 0.6 & 0.9 \\
\hline T. trachyspermus & 41.3 & 40.6 & 9.8 & 8.2 & 6.8 & 6.2 & 0.6 & 1.0 \\
\hline L.S.D $(p<0.05)$ & 4.1 & 6.1 & 2.4 & 1.4 & 1.9 & 1.4 & 0.3 & 0.3 \\
\hline
\end{tabular}

Phenolic content was found highest in Cephalosporium sp., $\left(0.68 \mathrm{mg} \mathrm{mL}^{-1}\right)$ treated plants than other treatments. Chaetomium sp., $\left(0.55 \mathrm{mg} \mathrm{mL}^{-1}\right), T$. assiutensis and T. trachyspermus $\left(0.53 \mathrm{mg} \mathrm{mL}^{-1}\right)$ showed increased in polyphenolic contents as compared to carbendazim treated plants $\left(0.41 \mathrm{mg} \mathrm{mL}^{-1}\right)$ and control plants $\left(0.17 \mathrm{mg} \mathrm{mL}^{-1}\right)$ (Fig. 3). Highest level of salicylic acid content was found in $T$. assiutensis treated plants $\left(0.60 \mathrm{mg} \mathrm{mL}^{-1}\right)$ followed by Cephalosporium sp., (0.54 mg mL $\left.{ }^{-1}\right)$, T. trachyspermus and Chaetomium sp., $\left(0.51 \mathrm{mg} \mathrm{mL}^{-1}\right)$ as compared to carbendazim treated plants $\left(0.33 \mathrm{mg} \mathrm{mL}^{-1}\right)$ and control plants $\left(0.16 \mathrm{mg} \mathrm{mL}^{-1}\right)$ (Fig. 4). Antioxidant activity of endophytic fungi treated plants was also found greater as compared to control plants, where T. trachyspermus showed highest activity (Fig. 5).

Effect of endophytic fungi on root rotting fungi and growth of sunflower in pot experiment (2018). Less numbers infection of $F$. oxysporum and $R$. solani was observed in all treatments including control plants, while $F$. solani significantly $(p<0.05)$ suppressed by all test endophytic fungi than control plants. Macrophomina phaseolina significantly suppressed in all treatments than control plants, where M. phaseolina was not found in T. trachyspermus treated plants (Table 4). All isolates of endophytic fungi treated plants produced greater fresh shoot weight and shoot length than control plants (Table 5).

Phenolic content was again found greater in plants treated with endophytic fungi as compared to control or carbendazim treated plants with highest in Cephalosporium sp., ( $\left.0.57 \mathrm{mg} \mathrm{mL}^{-1}\right)$ and lowest in control plants $\left(0.24 \mathrm{mg} \mathrm{mL}^{-1}\right)$ (Fig. 6). Salicylic acid content increased in all endophytic fungi treated plants than control or carbendazim treatments (Fig. 7). Highest level of salicylic acid content was found in $T$. assiutensis (0.62 mg $\mathrm{mL}^{-1}$ ) and lowest in carbendazim treated plants $\left(0.17 \mathrm{mg} \mathrm{mL}^{-1}\right)$. 
Antioxidant activity was found to be increase with time, at 1 minute maximum was found in plants treated with Cephalosporium sp. (46.2\%), while at 30 minutes antioxidant status increased in all plants treated with endophytic fungi. Maximum level was found in plants treated with Chaetomium sp. (69.8\%) as compared to control plants (16.9\%) at 30 minutes (Fig. 8 ).

Effect of endophytic fungi on sunflower growth and suppression of root rotting fungi in field experiment (2017). Significant suppression of root rot fungi was observed in Chaetomium sp. and T. trachyspermus treated plants at both time intervals i.e. $45 \mathrm{~d}$ and $60 \mathrm{~d}$ (Table 6). Cephalosporium sp. and T. assiutensis were found effective against F. oxysporum, R. solani, and M.phaseolina, at both time intervals. All endophytic fungi enhanced plant height and fresh shootweight than control plants (Table 7).

Table 6. Effects of endophytic fungi on the infection of Fusarium solani, F. oxysporum, Macrophomina phaseolina and Rhizoctonia solani of sunflower plants in field experiments.

\begin{tabular}{|c|c|c|c|c|c|c|c|c|c|c|c|c|c|c|c|c|}
\hline \multirow[t]{4}{*}{ Treatments } & \multicolumn{16}{|c|}{ Infection \% } \\
\hline & \multicolumn{4}{|c|}{ F. solani } & \multicolumn{4}{|c|}{ F. oxysporum } & \multicolumn{4}{|c|}{ M. phaseolina } & \multicolumn{4}{|c|}{ R. solani } \\
\hline & \multicolumn{2}{|c|}{2017} & \multicolumn{2}{|l|}{2018} & \multicolumn{2}{|l|}{2017} & \multicolumn{2}{|c|}{2018} & \multicolumn{2}{|l|}{2017} & \multicolumn{2}{|l|}{2018} & \multicolumn{2}{|l|}{2017} & \multicolumn{2}{|l|}{2018} \\
\hline & $45 d$ & $60 \mathrm{~d}$ & $45 d$ & $60 \mathrm{~d}$ & $45 d$ & $60 \mathrm{~d}$ & $45 d$ & $60 \mathrm{~d}$ & $45 d$ & $60 \mathrm{~d}$ & $45 d$ & $60 d$ & $45 d$ & $60 \mathrm{~d}$ & $45 d$ & $60 d$ \\
\hline Control & 25 & 31.2 & 37.5 & 43.7 & 18.7 & 25 & 12.5 & 25 & 43.7 & 50 & 61.2 & 75 & 18.7 & 25 & 12.5 & 25 \\
\hline Carbendazim & 25 & 25 & 18.7 & 25 & 12.5 & 12.5 & 6.2 & 18.7 & 25 & 43.7 & 37.5 & 43.7 & 12.5 & 18.7 & 12.5 & 18.7 \\
\hline Cephalosporium sp. & 18.7 & 25 & 6.2 & 12.5 & 0 & 12.5 & 0 & 0 & 18.7 & 25 & 18.7 & 25 & 0 & 0 & 0 & 0 \\
\hline Chaetomium sp. & 0 & 0 & 0 & 0 & 0 & 0 & 0 & 0 & 18.7 & 25 & 25 & 31.2 & 0 & 0 & 0 & 0 \\
\hline Talaromyces assiutensis & 18.7 & 25 & 12.5 & 25 & 0 & 0 & 0 & 0 & 25 & 25 & 12.5 & 18.7 & 6.2 & 12.5 & 12.5 & 18.7 \\
\hline $\begin{array}{l}\text { Talaromyces } \\
\text { trachyspermus }\end{array}$ & 0 & 0 & 0 & 0 & 6.2 & 12.5 & 6.2 & 18.7 & 0 & 6.25 & 0 & 12.5 & 0 & 0 & 0 & 0 \\
\hline $\mathrm{LSD}_{0.05}$ & Treat & ents $=$ & $.7^{1} ; \mathrm{P}$ & ogens & $=3.8$ & $\mathrm{me}=2$ & & & & & & & & & & \\
\hline
\end{tabular}

${ }^{1}$ In column, mean values showing differences more than LSD value are significantly different at $\mathrm{p}<0.05$

${ }^{2}$ In row, mean values showing differences more than LSD value for pathogens are significantly different at $p<0.05$

${ }^{3}$ In row, mean values showing differences more than LSD value for time are significantly different at $p<0.05$

Table 7. Effects of endophytic fungi on growth of sunflower plants under field condition

\begin{tabular}{|c|c|c|c|c|c|c|c|c|c|c|c|c|c|c|c|c|}
\hline \multirow[t]{3}{*}{ Treatments } & \multicolumn{4}{|c|}{ Shoot length $(\mathrm{cm})$} & \multicolumn{4}{|c|}{ Shoot weight (g) } & \multicolumn{4}{|c|}{ Root length (cm) } & \multicolumn{4}{|c|}{ Root weight (g) } \\
\hline & 2017 & & 2018 & & 2017 & & 2018 & & 2017 & & 2018 & & 2017 & & 2018 & \\
\hline & $45 d$ & $60 d$ & $45 d$ & $60 \mathrm{~d}$ & $45 d$ & $60 d$ & $45 d$ & $60 d$ & $45 d$ & $60 \mathrm{~d}$ & $45 d$ & $60 d$ & $45 \mathrm{~d}$ & $60 \mathrm{~d}$ & $45 d$ & $60 \mathrm{~d}$ \\
\hline Control & 57.5 & 73.7 & 64.4 & 74.3 & 37.3 & 48.7 & 36.7 & 61.4 & 7.4 & 8.1 & 7.7 & 9.9 & 7.6 & 11.5 & 10.5 & 12.9 \\
\hline Carbendazim & 72.5 & 104.2 & 78.6 & 90.9 & 61.6 & 113.2 & 61.5 & 115 & 11.7 & 11.8 & 10.6 & 14.1 & 12.6 & 16.5 & 14.3 & 18.7 \\
\hline $\begin{array}{l}\text { Cephalosporium } \\
\text { sp. }\end{array}$ & 98.7 & 150.1 & 102.5 & 129.8 & 83.6 & 193 & 93.3 & 170 & 14 & 20.5 & 13.8 & 19.9 & 14.7 & 19.1 & 15.2 & 23.2 \\
\hline Chaetomium sp. & 91.7 & 112.5 & 95.5 & 107.3 & 66.6 & 133 & 77.2 & 127 & 11.7 & 12.3 & 12 & 15.8 & 12.5 & 15 & 11.2 & 19.9 \\
\hline $\begin{array}{l}\text { Talaromyces } \\
\text { assiutensis }\end{array}$ & 84.7 & 101 & 88.7 & 100.6 & 56.1 & 98.6 & 60.4 & 113 & 10 & 12.32 & 10.2 & 12.4 & 7.8 & 8.4 & 10.7 & 15.8 \\
\hline $\begin{array}{l}\text { Talaromyces } \\
\text { trachyspermus }\end{array}$ & 92.2 & 131.5 & 99.3 & 112.6 & 74.7 & 143.7 & 77 & 130.5 & 12.2 & 14.7 & 9.5 & 16 & 10.6 & 14.5 & 12 & 20.7 \\
\hline $\mathrm{LSD}_{0.05}$ & $7.9^{1}$ & $10.3^{1}$ & $8.7^{1}$ & $8.9^{1}$ & $10.6^{1}$ & $27.8^{1}$ & $7.9^{1}$ & $29.5^{1}$ & $2.3^{1}$ & $2.8^{1}$ & $3.2^{1}$ & $4.1^{1}$ & $1.7^{1}$ & $2.3^{1}$ & $2.4^{1}$ & $2.3^{1}$ \\
\hline
\end{tabular}

${ }^{1}$ In column, mean values showing differences more than LSD values are significantly different at $p<0.05$

Concentrations of plant biomarkers like polyphenolic contents and salicylic acid were found significantly higher in endophytic fungi treated plants than control plants at both time intervals (Fig. 9, 10). Similarly, antioxidant status of endophytic fungi treated plants were found better than control plants at both time intervals (Fig. 11).

Effect of endophytic fungi on sunflower growth and suppression of root rotting fungi in field experiment (2018). All four test endophytic fungi, Cephalosporium sp., Chaetomium sp., T. assiutensis and T. trachyspermus significantly suppressed all four test pathogenic fungi on sunflower roots at both time intervals (Table 6). Highest activity against M. phaseolina was found by T. trachyspermus. Endophytic fungi treated plants again produced significantly taller plants with greater fresh shoot weight as compared to control plants (Table 7). 
The endophytic fungi treatment again found to improve production of polyphenolic content and salicylic acid with increasing antioxidant levels of plants as compared to control plants at both time intervals (Figs. 12,13 and 14). All four tests endophytic fungi showed a similar trend in suppressing root rot fungi and stimulating plant defense biochemical markers and improved antioxidant levels of the plant as found in a 2017 experiment.

Principal Component Analysis (PCA). A principal component analysis (PCA) was performed to highlight the high promising isolate for endophytes that promote sunflower growth and increased plant defense biochemical markers in pots and field plot experiments. Talaromyces trachyspermus was found more effective in improving plant biomass and enhanced plant defense biochemical markers in general both in pots and field experiments as compared to other isolates. The results are presented in (Figs. 15 and 16).

\section{Discussion}

Chemical pesticides are essential agents to minimize losses caused by plant pathogens to agricultural crops. Due to their adverse impact on nature, their applications are being reduced. There is a basic need for an emerging attempt to explore compounds which are nature-friendly and can be substituted for chemically synthesized commercial products. Alternate sources are more essential to synthesize natural products are not yet commercially feasible and are costly $^{25}$. To search for novel bioactive metabolites, microorganisms which make symbiotic association with plants are gaining special attention ${ }^{26}$. In this study, endophytic fungi isolated from healthy wild and cultivated plants and were identified by using molecular biological tools, showed potential against plant pathogenic fungi. These findings are an agreement with previous studies regarding the presence of potential fungi in plants as endophytes ${ }^{3,6,27,28}$. Each plant species is host specific to few or more endophytic fungi and they are considered as hyper diverse groups ${ }^{1}$. They are found in most of the known plants and plant-like organisms; liverworts and algae ${ }^{29}$. The relationship between host plants and their fungal endophyte range from symbiotic to mutualistic or sometimes antagonistic. It is described that diversity of fungal endophytes in ecologies, and there is no reliable estimation of endophytes yet, but environmental factors are one of the complex features ${ }^{30}$. However, some endophytes are predominant in specific hosts and some are rare ${ }^{31}$. In this study, some endophytic fungi isolated are also known as plant pathogens like Fusarium sp., and Macrophomina phaseolina that attack on a wide range of economically important plants ${ }^{22}$. However, Talaromyces isolated in this study are the perfect stage of Penicillium known to possess biocontrol potential ${ }^{32}$.

In this study, endophytic fungi showed significant antibacterial and antifungal activity in vitro. There are reports that fungal endophytes isolated from various plants have shown significant antimicrobial activity ${ }^{3,27}$. In this study, $n$-hexane and chloroform soluble portion of culture filtrates of endophytic fungi like Chaetomium sp., T.assiutensis and T. trachyspermus showed strong antimicrobial activity against root rotting fungi. In this study, $n$-hexane soluble portion of culture filtrate of T. trachyspermus revealed the presence of several compounds, when subjected to GC-MS analysis, and many of them appeared as new from this source. Secondary metabolites reported from Talaromyces are alkaloid ${ }^{33}$ terpene $^{34}$ and polyketide classes ${ }^{26,34}$ identified talaperoxides from an endophytic fungus Talaromyces flavus from medicinal plants showed potent cytotoxic activity against cancer cell lines. Presence of these compounds may play a vital role in antimicrobial activity of $T$. trachyspermus.

In this study endophytic fungi showed significant results on sunflowers both in pots and field plot experiments by reducing root rot incidence and improvement of plant biomass. Talaromyces spp. and Cephalosporium sp. showed the best result in improving the plant growth and suppressing plant pathogenic fungi on sunflowers. Active metabolites produced by fungal endophytes have a capability to act as a biological control agent and enhance plant growth and protect them from phyto-pathogens ${ }^{3}$. There is a report that Talaromyces flavus can suppress root rotting fungi on chickpeas ${ }^{35}$. T. trachyspermus is known to produce hydrolytic enzymes, chitinase, amylase, cellulose, protease and pectinase having antagonistic property along with producing indole acetic acid (IAA), siderophore, and solubilize phosphate which plays a role in plant growth promotion ${ }^{36}$. Cephalosporium spp., are well known for the production of cephalosporin like antibiotics Its role as a potential biological control agent against root rotting fungi is interesting, and needs further investigation.

Endophytic fungi used in our study also improved plant growth, and stimulated the production of plant defense biochemical markers like, polyphenolic content and salicylic acid (SA). Polyphenolic compounds work as antibiotics in plants and act as non-host resistance to filamentous fungi ${ }^{37}$ which improve antioxidant status of plant ${ }^{5,38}$. Similarly, salicylic acid (SA) has now been reported to increase plant resistance to abiotic and biotic stress ${ }^{39,40}$. It has also positive impacts on development of plant growth and regulation of uptake of the several plants based on beneficial elements ${ }^{41,42}$. SA also decreased oxidative stress by modulating their antioxidant defense systems ${ }^{43}$. The disease suppression in sunflower may be attributed due to enhance plant defense biochemical markers, besides producing antimicrobial compounds by endophytes, as evident from the production of higher amount of plant defense biochemical markers like, polyphenol content, salicylic acid and improving antioxidant status in plants. It seems that endophytic fungi associated with healthy plants could be an alternative to chemical pesticides in plant root diseases management.

\section{Materials And Methods}

Isolation of Endophytic fungi. Healthy plant samples viz., Allium cepa L., Chenopodium album L., Corchorus olitorius L., Euphorbia hirta L., Haloxylon stocksii (Boiss) Benth. \& Hook, Sida ovata Forssk., and Solanum melongena L., growing in the experimental field of Botany Department, Karachi University and agricultural field of Malir, Karachi were collected (along with root, shoot and leaves) and endophytic fungi were isolated within 24 hours. Permission of Chairman, Department of Botany and Campus Office was obtained for collecting the plants from the campus, whereas, plants collected from agricultural filed at Malir with the permission of Owner of the field. Identification of each plant species was confirmed by a taxonomist and herbarium number was assigned (Table 1). All the experiments were performed in accordance with institutional guidelines and regulations.

After washing with tap water, plant samples were cut into small pieces $\left(1 \mathrm{~cm}\right.$ long), then sterilized with $1 \%$ bleach $\left[\mathrm{Ca}(\mathrm{OCl})_{2}\right]$ for three minutes, followed by sterilization with $70 \%$ alcohol for three minutes and then with sterile water. Sample was crushed in $50 \mathrm{~mL}$ sterilized water by using an electric grinder and a 
dilution was made up to $1: 10^{4}$. From final dilution $0.1 \mathrm{~mL}$ was spread over Petri plates containing Potato Dextrose Agar (PDA) amended with streptomycin $(0.2 \mathrm{~g} / \mathrm{L})$ and Penicillin (100000 units/L). Fungi isolated after incubation at $28^{\circ} \mathrm{C}$ for 7 days were initially identified on morphological characters according to $44,45,46,47,48,49$. Identification of endophytic fungi was confirmed by using molecular biological tools.

Molecular identification of endophytic fungi. Fungal mycelium $\left(1.5-2 \mathrm{~cm}^{2}\right)$ was obtained from fresh culture in sterile Eppendorf tubes and the cell was disrupted with glass beads in liquid nitrogen. The DNA extracted by using Biobasic EZ-10 Spin Column, Fungal Genomic DNA Mini-Preps Kit, (CANADA) according to their manufacturer instructions. DNA quality was assessed by using Agarose gel electrophoresis while the purity of DNA was assessed by spectrophotometer (Shimadzu- UV-1800). The primer sets i.e., ITS1 region (5'-TCCGTAGGTGAACCTGCGG-3') and ITS4 region (3'-TCCTCCGCTTATTGATATGC$5^{\prime}$ ) used for amplification of rDNA ITS region. For the amplification of targeted region, each PCR reaction mixture comprised of fungal genomic DNA (100ng), $1.0 \mu \mathrm{L}$ of ITS1 primer (10pmole), $1.0 \mu \mathrm{L}$ of ITS4 (10 pmole), $12.5 \mu \mathrm{L}$ of 2X PCR Master Mix (Thermo Fisher Scientific, MA, USA) up to final volume $25 \mu \mathrm{L}$ with nuclease free water. PCR amplification was carried out on ABI 2700 thermal cycler (California, USA) using the following conditions: first hold for 5 minutes at $94{ }^{\circ} \mathrm{C}$ for DNA denaturation followed by 35 cycles of denaturation at $94^{\circ} \mathrm{C}$ for $45 \mathrm{sec}$, annealing at $55^{\circ} \mathrm{C}$ for 45 sec and extension at $72{ }^{\circ} \mathrm{C}$ for 1 minute, then second hold for $10 \mathrm{~min}$ at $72{ }^{\circ} \mathrm{C}$ after that hold at $4{ }^{\circ} \mathrm{C}$. Amplified products evaluated by using $2 \%$ Agarose gel electrophoresis at $100 \mathrm{~V}$ for 35 min. The amplified products were submitted to BGI Genomic Services (Shenzhen, Guangdong, China) for Sanger sequencing of both ITS1 and ITS4. The consensus sequences were retrieved from both sets of primers and the sequences were edited and aligned manually by using BioEdit software (Version 7.2.6). BLAST analysis carried out for the identification of fungal isolates. Phylogenetic relationships of all isolates constructed using neighbor joining (NJ) method with MEGA-X software (PMID: 29722887). Each Sequence submitted to NCBI Genbank.

Antifungal activity of endophytic fungi. Antifungal activity of endophytic fungi was determined against Rhizoctonia solani, Macrophomina phaseolina, Fusarium solani and F.oxysporum by using Dual culture plate assay. Test isolates were inoculated in Petri dishes having Czapek's dox agar and on its opposite side pathogenic fungi was placed and incubated at $28^{\circ} \mathrm{C}$ for $5-7$ days. Inhibition zone produced, if any was recorded ${ }^{50}$.

Antifungal activity of culture filtrates of endophytic fungi. Test fungi grown at $\left(25-30^{\circ} \mathrm{C}\right)$ for 15 days in $250 \mathrm{~mL}$ flasks containing $100 \mathrm{~mL}$ Czapek's Dox broth. The broths were filtered over Whatman \#1 filter paper in flask and exposed to chloroform vapors under laminar flow hood to kill fungal propagules. Thick sterile discs were impregnated with endophytic fungal culture filtrates at 20, 40 and 60 $\mathrm{L} / \mathrm{disc}$ and dried. Discs along with control (disc loaded with Czapek's Dox broth) and +ve control (carbendazim at $20 \mu \mathrm{g} / \mathrm{disc}$ ) were placed at the periphery of plates. Test fungi ( $5 \mathrm{~mm}$ disc) were inoculated in the center. Zone of inhibition, if any was recorded after 5-7 days of incubation at $30^{\circ} \mathrm{C}^{27}$.

Fractionation of culture filtrates of endophytic fungi. The culture filtrates (Chaetomium sp., T. assiutensis, T. trachyspermus) were extracted separately 3 times with $n$-hexane in a separating funnel. $n$-hexane insoluble fraction was further extracted with chloroform. Both fractions were dried separately on a rotary vacuum evaporator (Eyela-NE, Japan) and finally gummy mass was obtained ${ }^{51}$.

Antifungal activity of solvent fractions of endophytic fungal culture filtrates. Each fraction was re-dissolved in their respective solvent at $1.5 \mathrm{mg} / \mathrm{mL}$ and $5 \mathrm{~mm}$ diameter sterile disc of filter papers were loaded at $20 \mu \mathrm{l}(30 \mu \mathrm{g} / \mathrm{disc}), 40 \mu \mathrm{l}(60 \mu \mathrm{g} / \mathrm{disc})$ and $60 \mu \mathrm{l}(90 \mu \mathrm{g} / \mathrm{disc})$ and dried. Other details are the same as described in antifungal activity of culture filtrates of endophytic fungi.

Gas Chromatography-Mass Spectrometry (GC-MS). The $n$-hexane soluble portion was oily in nature, which was subjected to GC/MS analysis. GC/MS was conducted on Agilent (6890) Gas Chromatograph linked with Mass Spectrometer: Jeol, JMS: (600H). Operational mode was El having the ion source at 50oC and their electron energy then maintained at $70 \mathrm{eV}$. Carrier Gas Volume placed in a range of 1.0-5.0 $\mu \mathrm{L}$. Individual peaks of each compounds were assigned, their mass spectra and retention indices (RI) were matched online with National Institute of Standards and Technology, USA (NIST: Mass Spectrometry Data Center (mainlib) NIST\#: 352898 ID\#: 113419 DB) and finally compared with Science finder.

Biocontrol potential of endophytic fungi against root rotting fungi. Talaromyces assiutensis and T. trachyspermus isolated in this study were selected for further study as biocontrol agents against root rotting fungi, since other fungal isolates are well known plant pathogens or environmental contaminants. Efficacy of Talaromyces spp., was examined in pots and also in field plots, using sunflower (Helianthus annuus L.) as test crop. Efficacy of Talaromyces spp., was also compared with endophytic Chaetomium sp. (KUCC1359) and Cephalosporium sp. (KUCC1358) obtained from the culture collection center at University of Karachi.

Screen house experiments. The experiment was conducted in February, 2017, in clay pots containing sandy loam soil (15 cm diam.) at $1 \mathrm{Kg} / \mathrm{pot}$ and aqueous suspensions of endophytes Talaromyces assiutensis, T. trachyspermus, Chaetomium sp., and Cephalosporium sp., (107 cfu/mL), grown on potato dextrose broth ( $\mathrm{pH}$ 5.6) at room temperature were applied onto each pot ( $25 \mathrm{~mL} / \mathrm{pot}$ ). Soil was naturally infested with 3 to $13 \%$ colonization of $R$.solani, using sorghum seed as bait ${ }^{52}, 3000 \mathrm{cfu} / \mathrm{g}$ of soil of Fusarium spp., using soil dilution technique ${ }^{53}$ and $3-9$ sclerotia/g of soil of M.phaseolina, by using wet sieving and dilution technique ${ }^{54}$. Aqueous suspension $(25 \mathrm{~mL})$ of endophytes $\left(8 \times 107 \mathrm{CFU} \mathrm{mL}^{-1}\right)$ grown in potato dextrose broth (PDB) for 15 days at $28^{\circ} \mathrm{C}$ was drenched in each pot after placing the seeds, then covered with soil (about $1.5 \mathrm{~cm}$ ). Population of endophytes in suspension was determined by dilution plate method on potato dextrose agar using the formula:

\section{CFU per $\mathrm{mL}=$ Number of colonies on plate $\times$ Dilution factor}

Seeds of sunflower ( 6 seeds per pot) were sown in each pot and randomized with four replicates. Temperature ranged from $25^{0} \mathrm{C}-35^{\circ} \mathrm{C}$. Carbendazim $(200$ ppm in water) at $25 \mathrm{~mL}$ in each pot used as +ve control; untreated plants were kept as control. In each pot, four seedlings maintained and excess were removed after germination. Observations were recorded after 45 days, plants were uprooted, washed under the tap water, and then blot dried. Root length and 
shoot length were measured and their fresh weight was recorded on an electronic balance. To determine the incidence of infection of fungi on roots, tap roots were cut into $(1 \mathrm{~cm})$ pieces, surface sterilized with $1 \%$ bleach. The root pieces were transferred onto PDA plates containing antibiotics, streptomycin and Penicillin as described above. Fungi grown on root pieces after 5 days of incubation at $25^{\circ} \mathrm{C}$ were identified and infection (\%) of each fungus was calculated by using the formula 55 .

Number of plants infected by a fungus

Infection \% $=$

Total number of plants

The experiment was repeated in 2018 in similar conditions, in order to confirm the efficacy of endophytic fungi.

Field plot experiments. The experiment was also conducted in field plots ( $2 \times 2 \mathrm{~m}$ ) of the Department of Botany in 2017 and repeated in 2018 . Aqueous suspension of above mentioned endophytes applied in the planting row at $400 \mathrm{~mL}-12 \mathrm{~m}$. The sandy loam soil (pH 8.0) was infested naturally with root rotting fungi M.phaseolina (6-11 sclerotia / g soil), 7-16 \% colonization of R.solani, on seed of sorghum used as a bait, $3300 \mathrm{cfu} / \mathrm{g}$ of soil having Fusarium spp. Sunflower seeds (30 per $2 \mathrm{~m}$ row) were sown and watered after 2-3 days. Complete randomized block design was used in each experiment with 4 replicates. Carbendazim (200 ppm in water) at $400 \mathrm{~mL} / 2 \mathrm{~m}$ row served as +ve control. After 45 and 90 days, 4 plants from each row were uprooted, washed under tap water and data collected from plant growth, suppression of root infecting fungi and plant stress markers were determined.

The experiment was repeated in 2018 in similar conditions to confirm the efficacy of endophytic fungi.

Biochemical parameters. Leaves $(1 \mathrm{~g})$ from each plant sample were dried overnight at $70^{\circ} \mathrm{C}$ in an oven, crushed in $100 \mathrm{~mL}$ ethanol $(96 \% \mathrm{v} / \mathrm{v})$ and centrifuged at $504 \mathrm{~g}$ for 20 minutes. The supernatant was collected to analyze polyphenol, salicylic acid and antioxidant activity.

Estimation of polyphenols. The Folin-Ciocalteu reagent was used to determine the total phenolic content ${ }^{56}$, aliquots $(100 \mu \mathrm{L})$ were mixed with $2 \mathrm{~mL}$ of $\mathrm{Na}_{2} \mathrm{CO}_{3}(2 \% \mathrm{w} / \mathrm{v})$, kept for 2 minutes at room temperature and then Folin-ciocalteu phenol reagent $(100 \mu \mathrm{L}$ of $50 \%)$ was added, finally kept in dark for 30 minutes. Absorbance (at $720 \mathrm{~nm}$ ) was recorded and phenolic content was expressed in $\mathrm{mg}$ of Gallic acid equivalents (GAE)/g of dried sample.

Estimation of salicylic acid. Sample aliquot $(100 \mu \mathrm{L})$ was mixed with the freshly prepared $(0.1 \%)$ solution of ferric chloride, and volume was made up to $(3.0$ $\mathrm{mL}$ ). Absorbance was measured on a spectrophotometer at 540 nm. The results were expressed as salicylic acid equivalent (mg of SA per gram of dried extract $)^{57}$.

Determination of antioxidant activity. Antioxidant activity (leaves) was determined by using 2, 2-Di-phenyl-1-picrylhydrazyl (DPPH) as a free radical scavenging activity as described ${ }^{5}$, where aliquot $(0.2 \mathrm{~mL})$ was added in $(0.8 \mathrm{~mL})$ of $100 \mathrm{mM}$, Tris-HCl buffer $(\mathrm{pH} 7.4)$, mixed with $30 \mu \mathrm{M} \mathrm{DPPH}(1 \mathrm{~mL})$ and vortex finally. Their absorbance was recorded at $517 \mathrm{~nm}$ at 01 minutes, and at 30 minutes after keeping in dark, using $1 \mathrm{~mL}$ aqueous ethanol with $01 \mathrm{~mL}$ of DPPH served as a control. Following formula used to determine their activity:

Antioxidant activity $=\underline{\text { Absorbance of control }- \text { Absorbance of sample }} \quad \times 100$

Absorbance of control

Analysis of data. The data was analyzed by using software SPSS, Costat, one-way ANOVA for plant growth and biochemical parameters. Significant value at $\mathrm{P}<.005$ was calculated to compare the means. For fungal infection, two- or three-way ANOVA was used and least significant difference (LSD) was calculated at $P<0.05$. and their means were compared at significant level $(p<0.05)$. To highlight the performance of the most effective isolate of endophytic fungi on plant growth, production of resistance markers and antioxidant activity, Principal Component Analysis (PCA) was performed by using software CANOCO Engine Version $5.0^{58}$.

\section{Declarations}

\section{Acknowledgements}

Financial assistance (grant \# nrpu-4491) provided by the High Education Commission Islamabad, is sincerely acknowledged. We are thankful to Dr. Rubina Abid, Professor of Plant Taxonomy, Department of Botany, University of Karachi for the identification of plants. Help of Prof. Dr. Viqar Uddin Ahmad (now late), HEJ Research Institute of Chemistry, University of Karachi for GC-MS analysis is acknowledged. We are also thankful to Dr. Muhammad Faheem Siddiqui, Assistant Professor, Department of Botany for helping in Principal component analysis ordination and Dr. Muhammad Athar, California Department of Food and Agriculture, CA, USA for critical reading of the manuscript.

\section{Author contributions}

Hafiza Farhat, Faizah Urooj and Hafiza Asma Shafique collected the plants, isolated and identified the endophytic fungi and conducted experiments on sunflowers. Muhammed Irfan and Saima Majeed helped in the molecular identification of endophytic fungi. H. Farhat and Nida Sohail extracted metabolites from endophytic fungi, and did antifungal activity. GC-MS analysis was conducted by Sidra Fatima Hameedi. Syed Ehteshamul-Haque conceived and designed the study, supervised research work and improved the quality of the final version of manuscript. All authors read and approved the final manuscript. 


\section{Conflict of Interest}

No conflict of interest declared.

\section{References}

1. Strobel, G. \& B. Daisy, Bioprospecting for microbial endophytes and their natural products. Microbiol. Molecul. Biol. Rev. 67, 491-502. doi: 10.1128/MMBR.67.4.491-502.2003 (2003).

2. Zimmerman, N.B. \& P.M. Vitousek, Fungal endophyte communities reflect environmental structuring across a Hawaiian landscape. Proc. Nat. Acad. Sci. 109, 13022-13027. doi: 10.1073/pnas.1209872109 (2012).

3. Urooj, F. Farhat, H. Ali, S. A. Ahmed, M. Sultana, V. Shams, Z. I. \& Ehteshamul-Haque S, Role of endophytic Penicillium species in suppressing the root rotting fungi of sunflower. Pak. J. Bot. 50, 1621-1628 (2018).

4. Rudgers, J.A. Holah, J. Orr, S. P. \& Clay K, Forest succession suppressed by an introduced plant-fungal symbiosis. Ecol. 88, $18-25$. https://doi.org/10.1890/0012-9658(2007)88[18:FSSBAl]2.0.C0;2 (2007).

5. Rahman, A. Sultana V, Ara J, \& Ehteshamul-Haque S, Induction of systemic resistance in cotton by the neem cake and Pseudomonas aeruginosa under salinity stress and Macrophomina phaseolina infection. Pak. J. Bot. 48, 1681-1689. http://dx.doi.org/10.6064/2012/963401 (2016).

6. Urooj, F. Farhat, H. Tariq, A. Moin, S. Sohail, N. Sultana, V. Hameedi, S. F. Shams, Z. I, \& Ehteshamul-Haque S, Role of endophytic Penicillium species and Pseudomonas monteilii in inducing the systemic resistance in okra against root rotting fungi and their effect on some physiochemical properties of okra fruit. J. Appl. Microbiol. https://doi.org/10.1111/jam.14894 2020.

7. Moin, S., Ali S A, Hasan K A, Tariq A, Sultana V, Ara J \& Ehteshamul-Haque S, Managing the root rot disease of sunflowers with endophytic fluorescent Pseudomonas associated with healthy plants. Crop Protect. 130, 105066. https://doi.org/10.1016/j.cropro.2019.105066 (2020).

8. Rodriguez, R. \& R. Redman, More than 400 million years of evolution and some plants still can't make it on their own: plant stress tolerance via fungal symbiosis. J. of Exp. Bot. 59, 1109-1114. (2008)

9. Hartley, S.E. \& A.C. Gange, Impacts of plant symbiotic fungi on insect herbivores: mutualism in a multitrophic context. Annual Rev. Entomol. 54, 323-342. (2009).

10. Latz, M.A., C, Birgit Jensen, David B, Collinge Hans J L, \& Jørgensen, Endophytic fungi as biocontrol agents: elucidating mechanisms in disease suppression. Plant Ecol. Divers. 11, 555-567. doi: 10.1080/17550874.2018.1534146. (2018).

11. Khan, A.L. \& I.-J. Lee, Endophytic Penicillium funiculosum LHL06 secretes gibberellin that reprograms Glycine max L. growth during copper stress. BMC Plant biol. 13, 86. https://doi.org/10.1186/1471-2229-13-86 (2013).

12. Hossain, M.M., Sultana F, Kubota M, Koyama H, \& Hyakumachi M, The plant growth-promoting fungus Penicillium simplicissimum GP17-2 induces resistance in Arabidopsis thaliana by activation of multiple defense signals. Plant Cell Physiol. 48, 1724-1736. (2007).

13. Waqas, M., Khan A L, Hamayun M, Shahzad R, Kang SM, Kim JG, \& Lee I, J, Endophytic fungi promote plant growth and mitigate the adverse effects of stem rot: an example of Penicillium citrinum and Aspergillus terreus. J. Plant Interactions. 10, 280-287. doi: 10.1080/17429145.2015.1079743. (2015)

14. Ikram, M., Ali N, Jan G, Jan FG, Rahman IU, \& Iqbal A, IAA producing fungal endophyte Penicillium roqueforti Thom., enhances stress tolerance and nutrients uptake in wheat plants grown on heavy metal contaminated soils. PLoS One, 13, e0208150. https://doi.org/10.1371/journal.pone.0208150 (2018).

15. Stinson, M., Ezra D, Hess W M, Sears J, \& Strobel G, An endophytic Gliocladium sp. of Eucryphia cordifolia producing selective volatile antimicrobial compounds. Pl. Sci. 165, 913-922.(2003).

16. Gonzalez, F., Tkaczuk C, Dinu M M, Fiedler Ż, Vidal S, Zchori-Fein E, \& Messelink G J, New opportunities for the integration of microorganisms into biological pest control systems in greenhouse crops. J. Pest Sci. 89, 295-311.(2016).

17. Aly, A.H., A. Debbab, \& P. Proksch, Fungal endophytes: unique plant inhabitants with great promises. Appl. Microbiol. 90, 1829-1845. (2011).

18. Fouda, A.H. Hassan S E D \& Eid Ewais E E D, Biotechnological applications of fungal endophytes associated with medicinal plant Asclepias sinaica (Bioss.). Ann. Agric. Sci. 60, 95-104. http://dx.doi.org/10.1016/j.aoas.2015.04.001 (2015).

19. Liarzi, O., Bucki P, Miyara S B, \& Ezra D, Bioactive volatiles from an endophytic Daldinia cf. concentrica isolate affects the viability of the plant parasitic nematode Meloidogyne javanica. PLoS One, 11, e0168437.(2016)

20. Moin, S. Rahman A, Korejo F, Shafique H A, Zehra R, Sultana V, \& Ehteshamul-Haque S, amelioration of systemic resistance in tomato against root rotting fungi by the endophytic trichoderma species. Pak. J. Bot. 53, 1. doi: 10.30848/PJB2021-1(25) (2020b)

21. Katan, J., Diseases caused by soilborne pathogens: biology, management and challenges. J. Plant Pathol. 99, 305-315.(2017).

22. Parveen, G., Urooj F, Moin S, Farhat H, Fahim H F, \& Ehteshamul-Haque S, Estimation of losses caused by root rotting fungi and root knot nematodes infecting some important crops in lower sindh and hub, balochistan of Pakistan. Pak. J. Bot. 52, 673-678 http://dx.doi.org/10.30848/PJB2020-2(15) (2020).

23. Mukhtar, I., Sunflower disease and insect pests in Pakistan: A review. Afr. Crop Sci. J. 17, (2009).

24. Khan, A.N., Shair F, Malik K, Hayat Z, Khan M A, Hafeez F Y, \& Hassan M N, Molecular identification and genetic characterization of Macrophomina phaseolina strains causing pathogenicity on sunflowers and chickpea. Front. Microbiol. 8, 1309. https:// doi.org/10.3389/ fmicb.2017.01309. (2017).

25. Pereira, S. \& P. Castro, Diversity and characterization of culturable bacterial endophytes from Zea mays and their potential as plant growth-promoting agents in metal-degraded soils. Envir. Sci. Pollut. Res. 21, 14110-14123.(2014).

Page $11 / 20$ 
26. Guo, J., Ran H, Zeng J, Liu D \& Xin Z, Tafuketide, a phylogeny-guided discovery of a new polyketide from Talaromyces funiculosus Salicorn 58. Appl. Microbiol. Biotechnol. 100, 5323-5338. (2016).

27. Farhat, H., Urooj F, Tariq A, Sultana V, Ansari M, Ahmad V U, \& Ehteshamul-Haque S, Evaluation of antimicrobial potential of endophytic fungi associated with healthy plants and characterization of compounds produced by endophytic Cephalosporium and Fusarium solani. Biocatal. Agric. Biotechnol. 18, 101043.(2019)

28. Kogel, K.-H., P. Franken, \& R. Hückelhoven, Endophyte or parasite-what decides? Curr. Opinion in PI. Biol. 9 358-363.(2006)

29. Higginbotham, S.J., Arnold A E, Ibañez A, Spadafora C, Coley P D, \& Kursar T A, Bioactivity of fungal endophytes as a function of endophyte taxonomy and the taxonomy and distribution of their host plants. PloS one. 8, e73192. (2013).

30. Arnold, A.E., Mejía L C, Kyllo D, Rojas E.I, Maynard Z, Robbins N, \& Herre E.A, Fungal endophytes limit pathogen damage in a tropical tree. Proce. Nat. Acad. Sci. 100, 15649-15654.(2003)

31. Bernardi-Wenzel, J., García A, Celso Filho J R, Prioli A J, \& Pamphile J A, Evaluation of foliar fungal endophyte diversity and colonization of medicinal plant Luehea divaricata (Martius et Zuccarini). Biol. Res. 43, 375-384.(2010).

32. Madi, L., Katan T, Katan J, \& Henis Y, Biological control of Sclerotium rolfsii and Verticillium dahliae by Talaromyces flavus is mediated by different mechanisms. Phytopath. 87, 1054-1060.(1997)

33. Chu, Y. S., Niu X M, Wang YL, Guo J P, Pan W Z, Huang X W, \& Zhang K Q, Isolation of putative biosynthetic intermediates of prenylated indole alkaloids from a thermophilic fungus Talaromyces thermophilus. Org. Lett. 12, 4356-4359 (2010).

34. Li, H., Huang H, Shao C, Huang H, Jiang J, Zhu X, \& Lin Y, Cytotoxic norsesquiterpene peroxides from the endophytic fungus Talaromyces flavus isolated from the mangrove plant Sonneratia apetala. J. Natur. Prod. 74, 1230-1235. (2011)

35. Ehteshamul-Haque, S., Zaki M J, Abid M, \& Ghaffar A, Use of Verticillium chlamydosporium in the biological control of root rot disease of chick pea. Pak. J. Bot. 26, 229-234.(1994).

36. Sahu, S., A. Prakash, \& K. Shende, Talaromyces trachyspermus, an endophyte from Withania somnifera with plant growth promoting attributes. J. Environ. Sustain., 2, 13-21. https://doi.org/10.1007/s42398-019-00045-5 (2019).

37. Lattanzio, V., V.M. Lattanzio, \& A. Cardinali, Role of phenolics in the resistance mechanisms of plants against fungal pathogens and insects. Phytochemistry: Advances in research, 661, 23-67.(2006).

38. Shafique, H.A., Noreen R, Sultana V, Ara J, \& Ehteshamul-Haque S, Effect of endophytic Pseudomonas aeruginosa and Trichoderma harzianum on soilborne diseases, mycorrhizae and induction of systemic resistance in okra grown in soil amended with Vernonia anthelmintica (L.) seed's powder. Pak. J. Bot. 47, 2421-2426.(2015)

39. Khan, M.I.R., Fatma M, Per TS, Anjum NA, \& Khan NA, Salicylic acid-induced abiotic stress tolerance and underlying mechanisms in plants. Front. Plant Sci. 6, 462. doi: 10.3389/fpls.2015.00462. (2015)

40. Shafique, H.A.S., Viqar. Ehteshamul-Haque, Syed. Athar, \& Mohammad., Management of soil-borne diseases of organic vegetables. J. PI. Protect. Res. 56, (2016).

41. Senaratna, T., Touchell D, Bunn E, \& Dixon K, Acetyl salicylic acid (Aspirin) and salicylic acid induce multiple stress tolerance in bean and tomato plants. Plant Growth Regul. 30, 157-161.(2000)

42. Wang, C., Zhang S, Wang P, Hou J, Qian J, \& Ao Y, Salicylic acid involved in the regulation of nutrient elements uptake and oxidative stress in Vallisneria natans (Lour.) Hara under Pb stress. Chemosphere, 84, 136-42. doi: 10.1016/j.chemosphere (2011).

43. Shirasu, K., Nakajima A, Rajshekar K, Dixon R A, \& Lamb C, Salicylic acid potentiates an agonist-dependent gain control that amplifies pathogen signals in the activation of defense mechanisms. Plant Cell. 1997. 9, 261-270.(1997).

44. Barnett H L, \& Hunter, B.B, Illustrated Genera of Imperfect Fungi. $4^{\text {th }}$ ed. APS press, Minnesota, USA. (1998)

45. Ellis M B, 'Dematiaceous Hyphomycetes'. Commonwealth Mycological Institute: Kew, Surrey, UK. (1971)

46. Booth C, The Genus Fusarium. - Commonwealth Mycological Institute, Kew, Surrey, England. 237. (1971)

47. Domsch K H, Gams W, \& Anderson TH, 'Compendium of soil fungi', Vol. I. Academic Press (London) Ltd. (1980)

48. Nelson P E, Toussoun TA, \& Marasas W F O, Fusarium species: An illustrated manual for identification. Pennsylvania, USA: Pennsylvania State University Press. (1983)

49. Dugan FM, The Identification of Fungi: An Illustrated Introduction with Key, Glossary and Guide to Literature. The American Phytopathological Society, St. Paul. Minnesota., 184. (2006)

50. Korejo F, Ali S A, Shafique H A, Sultana V, Ara J, \&Ehteshamul-Haque S, Antifungal and antibacterial activity of endophytic Penicillium species isolated from Salvadora species. Pak. J. Bot. 46, 2313-2318. (2014)

51. Hameed S, Sultana V, Ara J, Ehteshamul-Haque S, \& Athar M. Toxicity of Fusarium solani strains on brine shrimp (Artemia salina). Zool. Res. 30 468-472. (2009)

52. Wilhelm, S. . Verticillium wilt of the strawberry with special reference to resistance. Phytopath., 45, 387-391. (1955)

53. Nash, S. M. \&amp; Snyder, W. C. (1962). Quantitative estimations by plate counts of propagules of the bean root rot Fusarium in field soils. Phytopath., 52(6): 123-144.

54. Sheikh, A.H. \& A. Ghaffar. . Population study of the sclerotia of Macrophomina phaseolina in cotton fields. Pak. J. Bot. 7, 13-17. (1975)

55. Noreen R, Ali S A, Hasan K A, Sultana V, Ara J, \& Ehteshamul-Haque S, Evaluation of biocontrol potential of fluorescent Pseudomonas associated with root nodules of mungbean, Crop Protect 75, 18-24. (2015)

Page $12 / 20$ 
56. Chandini S K, Ganesan P, \& Bhaskar N , In vitro antioxidant activities of three selected brown seaweeds of India. Food Chem 107, 707-713. (2008)

57. Warrier RR, Paul M, \& Vineetha MV , Estimation of salicylic acid in Eucalyptus leaves using spectrophotometric methods. Gen. PI. Physio/3, 90-97. (2013)

58. Ter Braak C J F, Quantitative methods in life and earth sciences. Plant Research International. Wageningen University and Research Centre, Wageningen, The Netherlands. (2012)

\section{Figures}

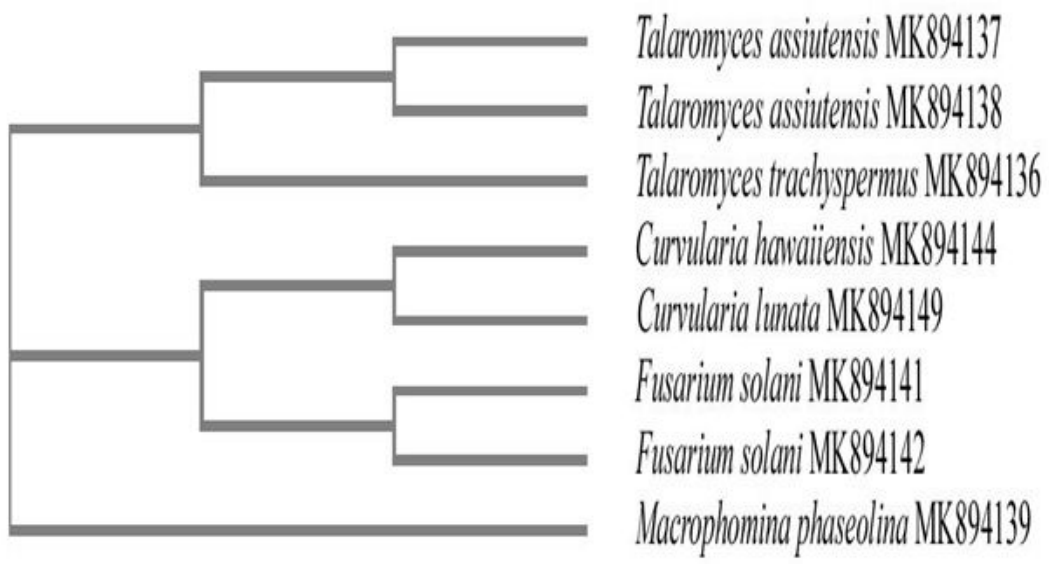

Figure 1

Molecular bases of endophytic fungi showing their ancestral relationship and their accession number downloaded from NCBI. 


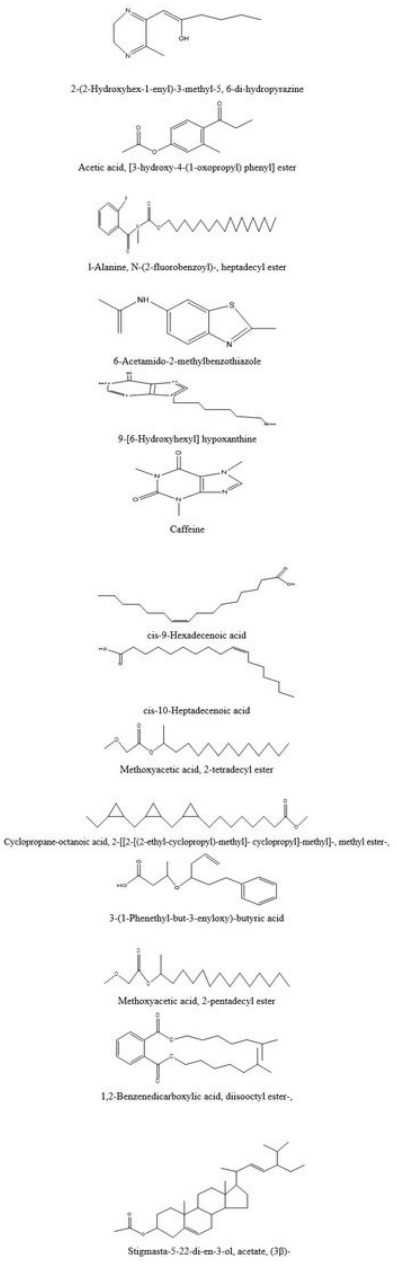

\section{Figure 2}

New compounds identified from n-hexane soluble fraction of culture filtrate of Talaromyces trachyspermus.

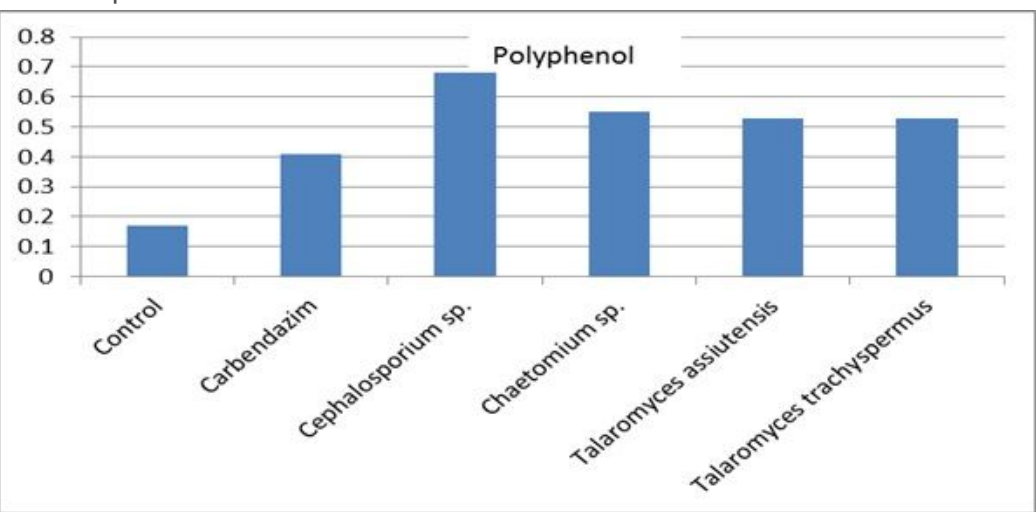

Figure 3

Effect of endophytic fungi as soil drench on polyphenol content of sunflower plants in pots experiment (2017). 


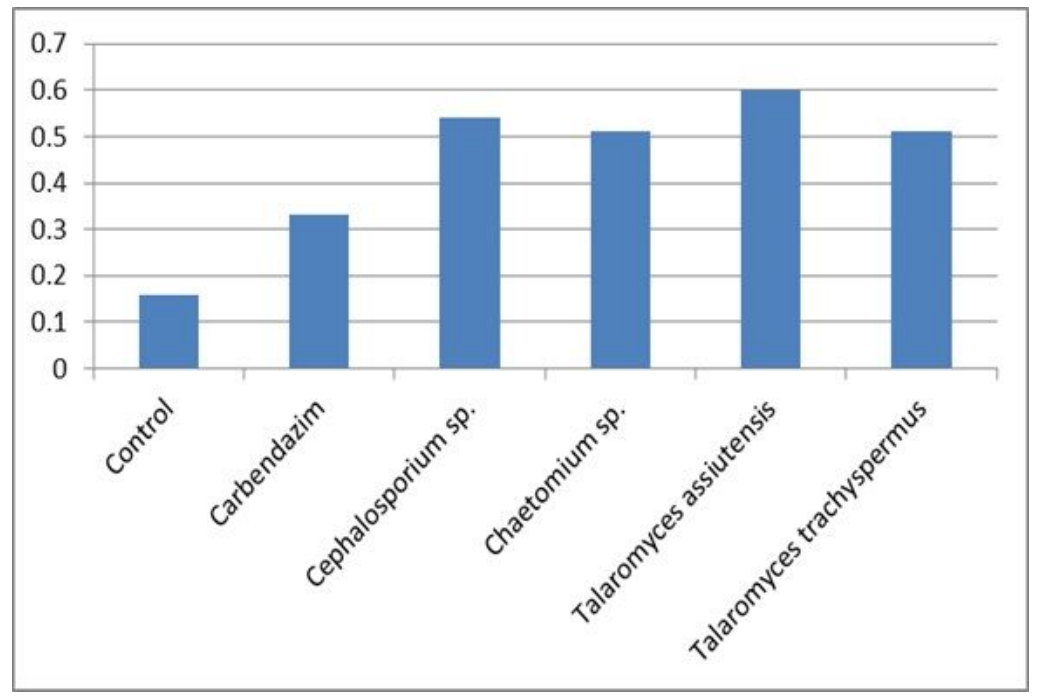

Figure 4

Effect of endophytic fungi as soil drench on salicylic acid of sunflower plants in pots experiment (2017).

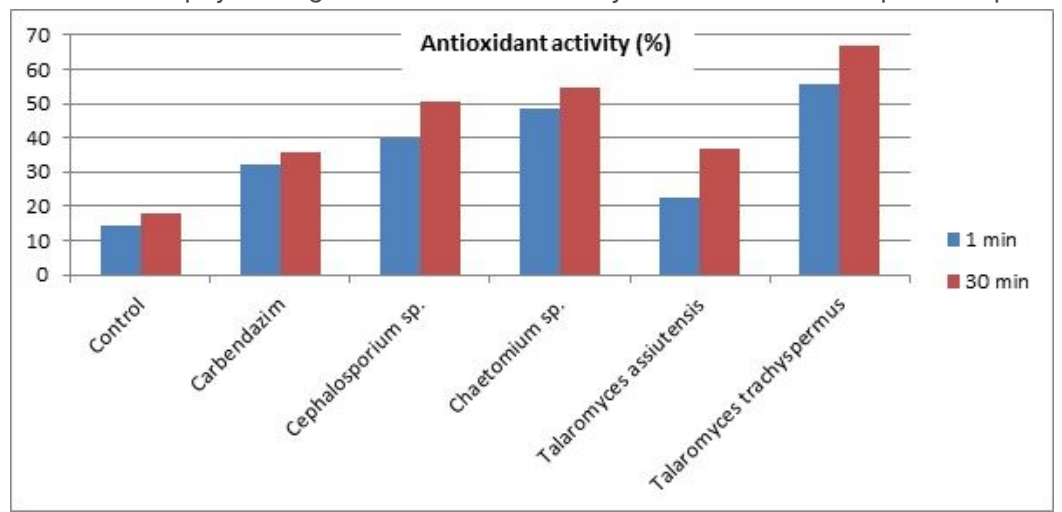

\section{Figure 5}

Effect of endophytic fungi as soil drench on antioxidant activity of sunflower plants in pots experiment (2017).

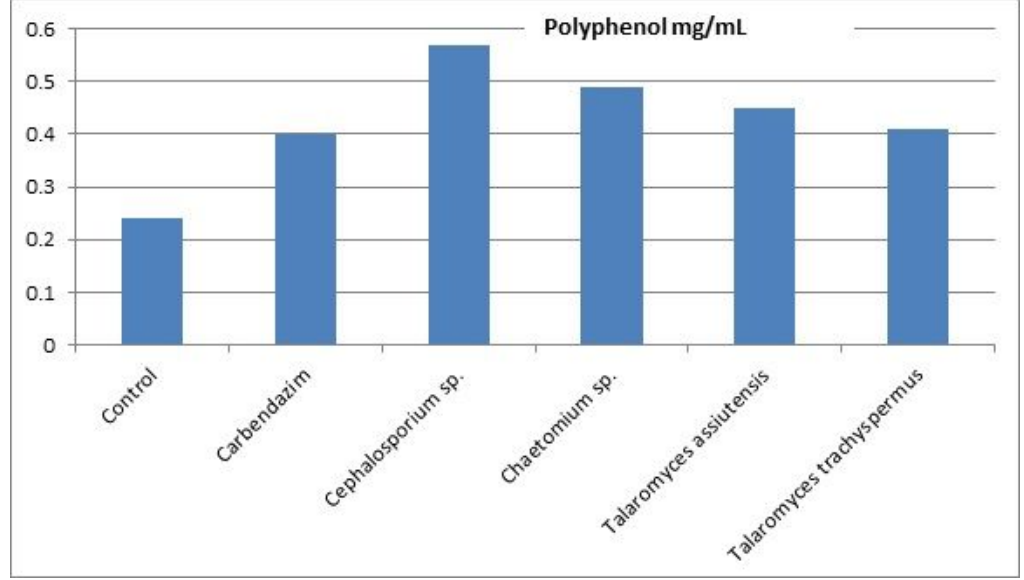

\section{Figure 6}

Effect of endophytic fungi as soil drench on polyphenol content of sunflower plants in pots experiment (2018). 


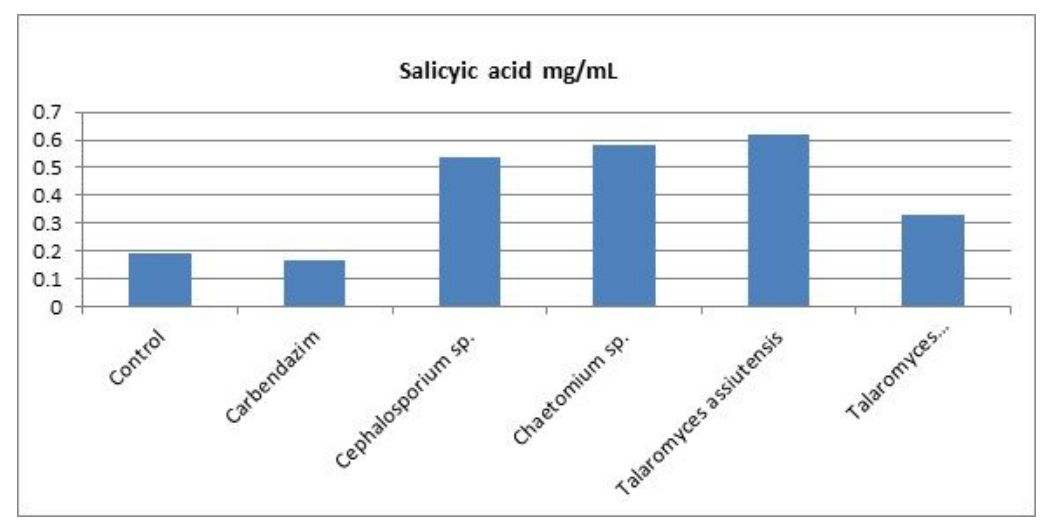

\section{Figure 7}

Effect of endophytic fungi as soil drench on salicylic acid of sunflower plants in pots experiment (2018).

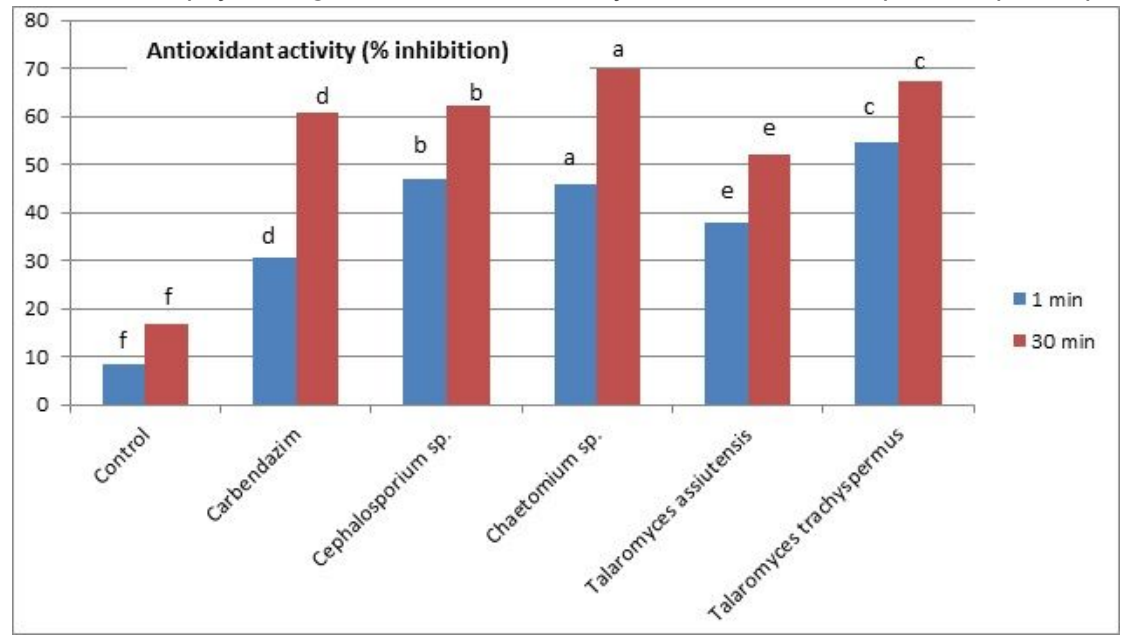

\section{Figure 8}

Effect of endophytic fungi as soil drench on antioxidant activity of sunflower plants in pots experiment (2018).

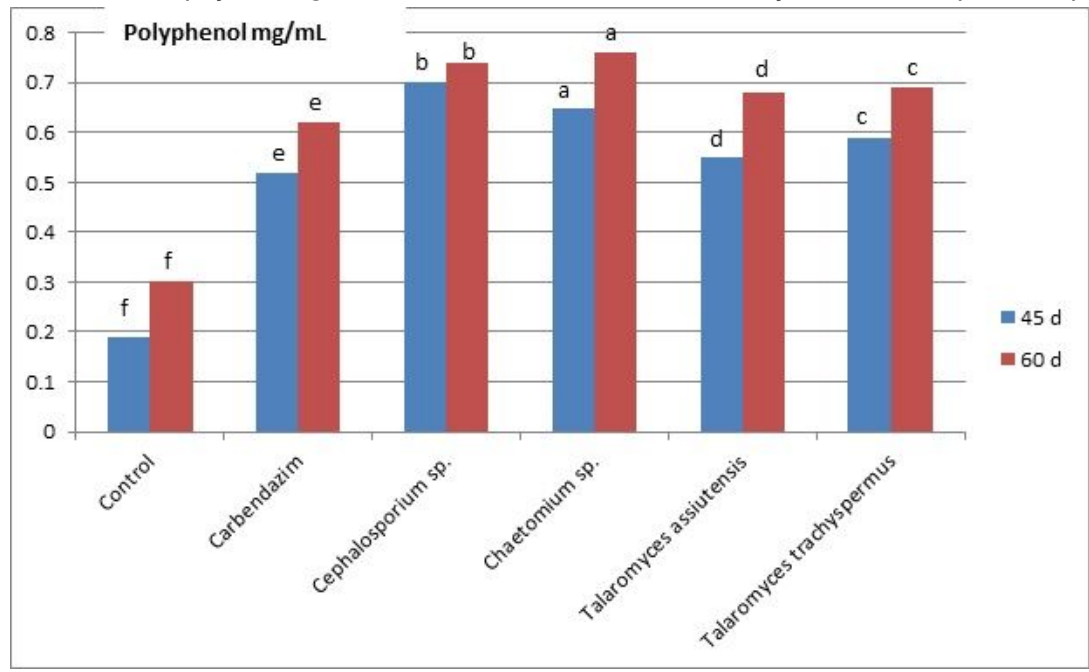

\section{Figure 9}

Effect of endophytic fungi as soil drench on polyphenol content of sunflower plants in field experiment (2017). 


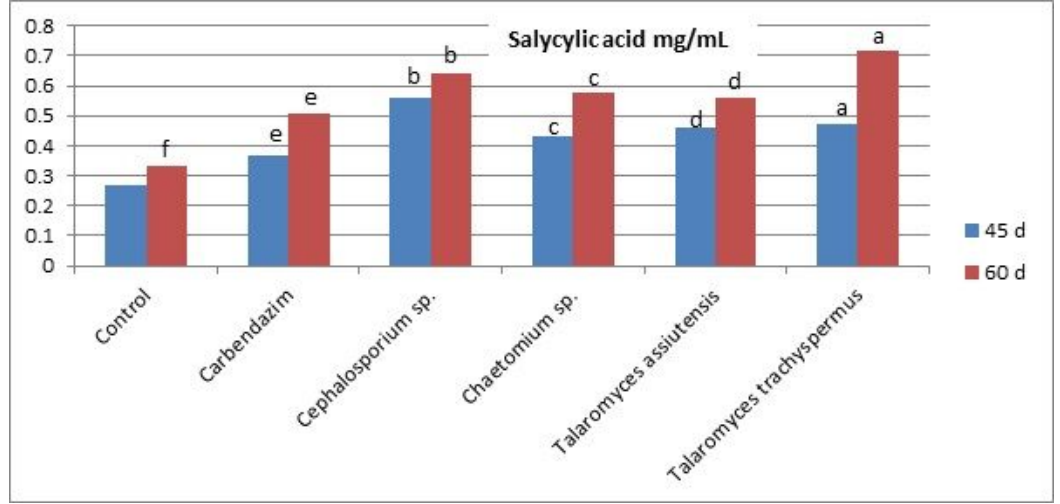

\section{Figure 10}

Effect of endophytic fungi as soil drench on salicylic acid of sunflower plants in field experiment (2017).

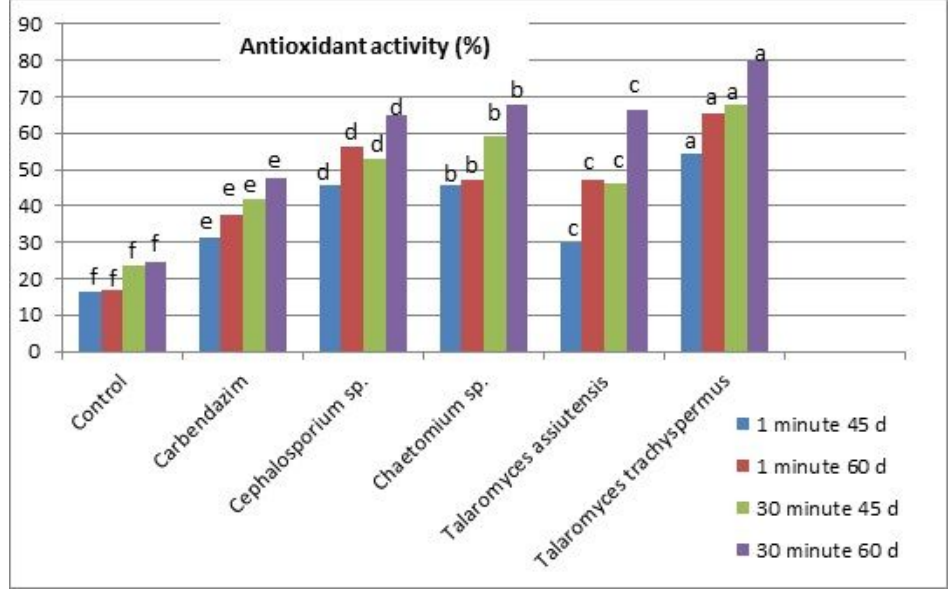

\section{Figure 11}

Effect of endophytic fungi as soil drench on antioxidant activity of sunflower plants in field experiment (2017)

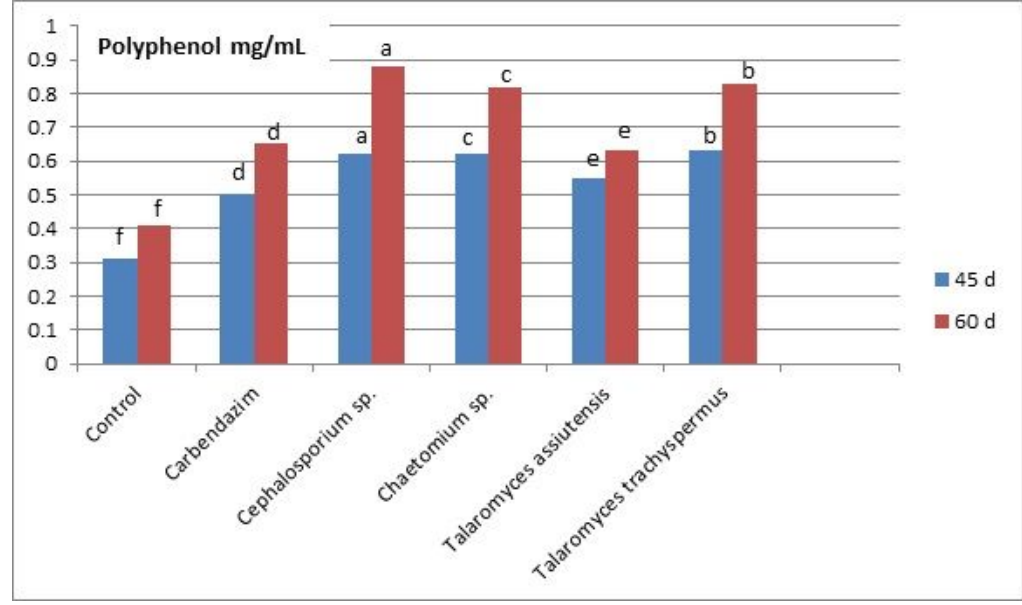

\section{Figure 12}

Effect of endophytic fungi as soil drench on polyphenol content of sunflower plants in field experiment (2018). 


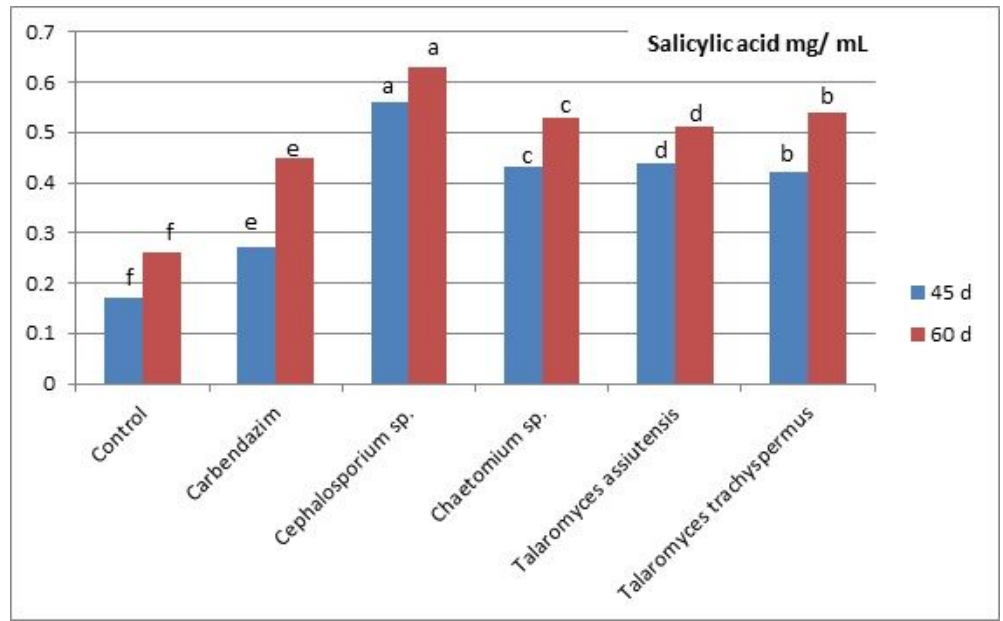

\section{Figure 13}

Effect of endophytic fungi as soil drench on salicylic acid of sunflower plants in field experiment (2018).

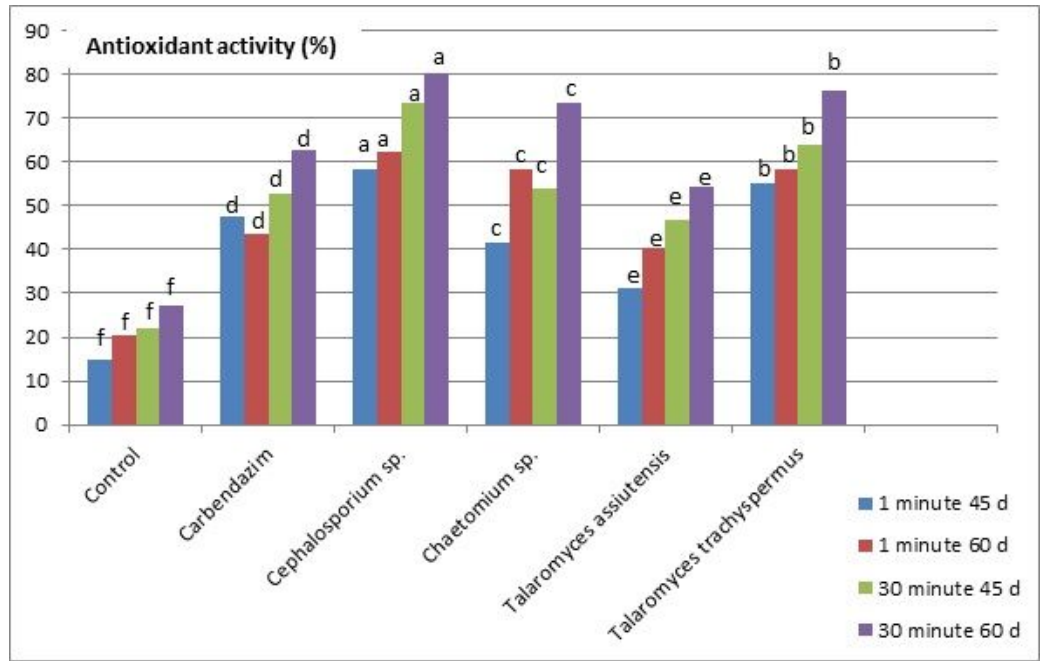

\section{Figure 14}

Effect of endophytic fungi as soil drench on antioxidant activity of sunflower plants in field experiment (2018). 
Pots experiment- 2017

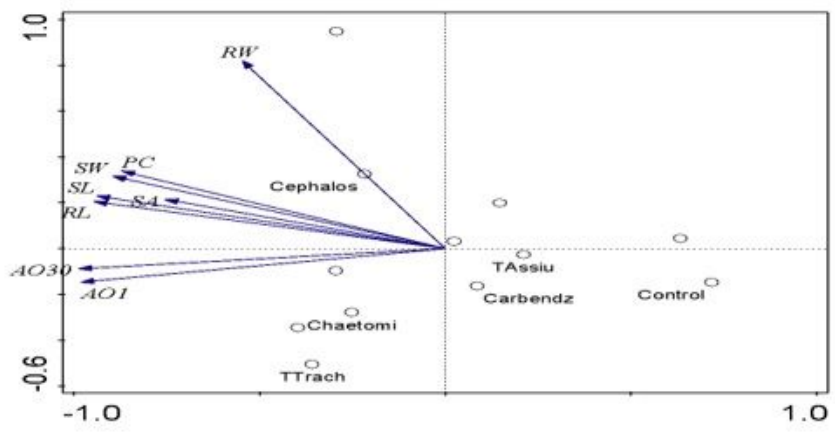

Pots Experiment 2018

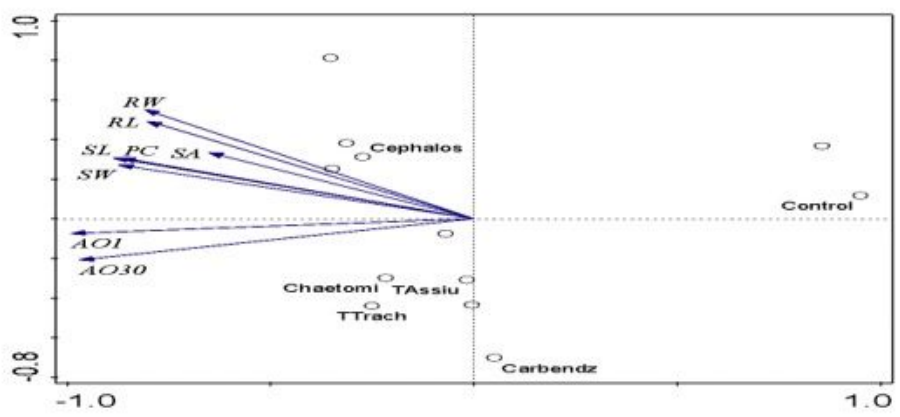

Figure 15

Bioplots are showing the principal component analysis (PCA1 and PCA2) of plant growth parameters, concentration of plant defense biochemical markers in sunflower and antioxidant activity due to endophytic fungi as compared to control plants. RW= root weigh, RL= root length, $S L=-$ shoot length, $S W=$ shoot weight, $\mathrm{SA}=$ salicylic acid, $\mathrm{PC}=$ polyphenolic content, $\mathrm{AO} 1=$ antioxidant activity at 1 mimute, $\mathrm{AO} 30=$ antioxidant activity at 30 minutes. Control= control, Carbendz $=$ carbendazim, Chaetomi $=$ Chaetomium sp., Cephalos $=$ Cephalosporium, $T A s s i u=$ Talaromyces assiutensis, $T$ Trach $=T$. trachyspermus

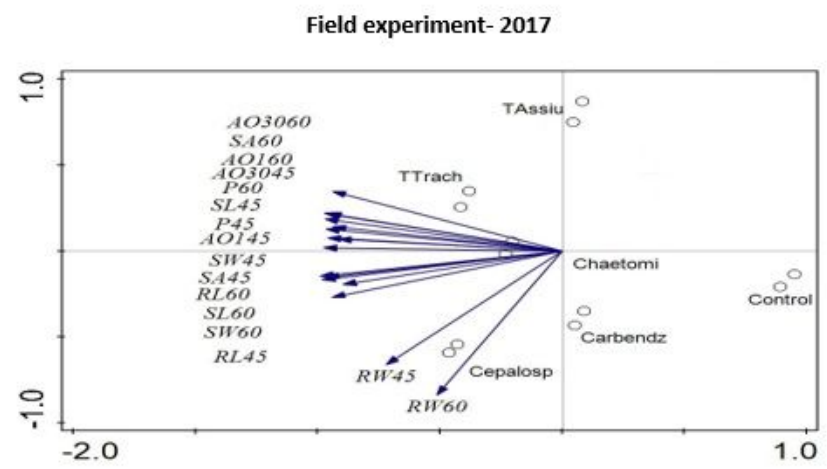

Field experiment 2018

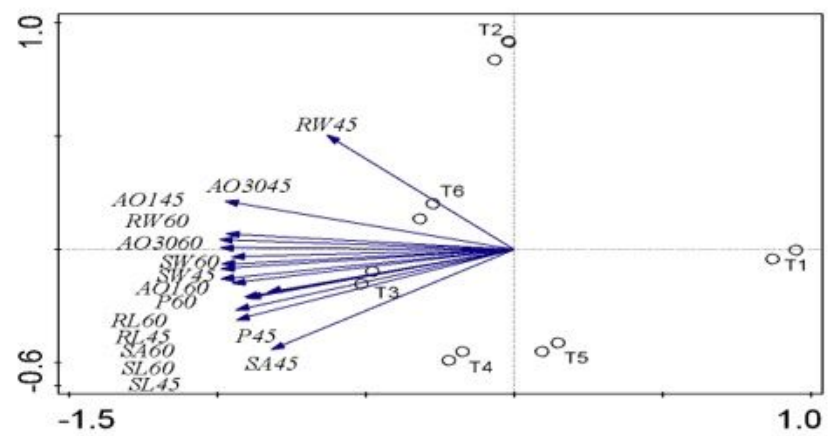

Figure 16 
Bioplots are showing the principal component analysis (PCA1 and PCA2) of plant growth parameters, concentration of plant defense biochemical markers in sunflower leaves and antioxidant activity due to PGPEF as compared to control plants. . RW45= root weigh at $45 \mathrm{~d}$, RL45= root length at $45 \mathrm{~d}$, SL45=- shoot length at $45 \mathrm{~d}$, SW45= shoot weight at $45 \mathrm{~d}$, SA45= salicylic acid at $45 \mathrm{~d}, \mathrm{PC} 45=$ polyphenolic content at 45, A0145= antioxidant activity at 1 minute at $45 \mathrm{~d}$, A03045= antioxidant activity at 30 minutes at $45 \mathrm{~d}$. RW60 = root weigh at $60 \mathrm{~d}, \mathrm{RL} 60=$ root length at $60 \mathrm{~d}, \mathrm{SL} 60=-$ shoot length at $60 \mathrm{~d}, \mathrm{SW} 60=$ shoot weight at $60 \mathrm{~d}, \mathrm{SA} 60=$ salicylic acid at $60 \mathrm{~d}, \mathrm{PC} 60=$ polyphenolic content at $60 \mathrm{~d}, \mathrm{AO} 160=$ antioxidant activity at 1 minute at $60 \mathrm{~d}, \mathrm{AO} 060=$ antioxidant activity at 30 minutes at $60 \mathrm{~d}$. T1 = control, T2= carbendazim, T3= Chaetomium sp., T4= Cephalosporium, T5= Talaromyces assiutensis, T6 T. trachyspermus

\section{Supplementary Files}

This is a list of supplementary files associated with this preprint. Click to download.

- HafizaFarhattablePGPEFSunflower050320211.docx

- HafizaFarhatPGPEFsupplemmentaryDataSunflower050320211.docx 